\title{
Conditional biallelic Nf2 mutation in the mouse promotes manifestations of human neurofibromatosis type 2
}

\author{
Marco Giovannini, ${ }^{1,2,4}$ Els Robanus-Maandag, ${ }^{2,4}$ Martin van der Valk, ${ }^{2}$ Michiko Niwa-Kawakita, ${ }^{1}$ \\ Vincent Abramowski, ${ }^{1}$ Laurence Goutebroze, ${ }^{1}$ James M. Woodruff, ${ }^{3}$ Anton Berns, ${ }^{2}$ and Gilles Thomas ${ }^{1,5}$ \\ ${ }^{1}$ INSERM U434, Fondation Jean Dausset, CEPH, 75010 Paris, France; ${ }^{2}$ Division of Molecular Genetics, Department \\ of Animal Pathology, and Centre for Biomedical Genetics, The Netherlands Cancer Institute, 1066 CX Amsterdam, \\ The Netherlands; ${ }^{3}$ Department of Pathology, Memorial Sloan-Kettering Cancer Center, New York, New York 10021 USA
}

Hemizygosity for the NF2 gene in humans causes a syndromic susceptibility to schwannoma development. However, Nf2 hemizygous mice do not develop schwannomas but mainly osteosarcomas. In the tumors of both species, the second $\mathrm{N} f 2$ allele is inactivated. We report that conditional homozygous $\mathrm{N} f 2$ knockout mice with Cre-mediated excision of $\mathrm{Nf2}$ exon 2 in Schwann cells showed characteristics of neurofibromatosis type 2. These included schwannomas, Schwann cell hyperplasia, cataract, and osseous metaplasia. Thus, the tumor suppressor function of $N f 2$, here revealed in murine Schwann cells, was concealed in hemizygous $N f 2$ mice because of insufficient rate of second allele inactivation in this cell compartment. The finding of this conserved function documents the relevance of the present approach to model the human disease.

[Key Words: Neurofibromatosis type 2; schwannomin; Schwann cell tumors; tumor suppressor gene; conditional knockout mice; Cre/lox $P]$

Received April 7, 2000; revised version accepted May 2, 2000.

Neurofibromatosis type 2 (NF2) is a dominantly inherited genetic disorder characterized by the development of bilateral vestibular schwannomas, schwannomas of other cranial, spinal, and cutaneous nerves, as well as cranial and spinal meningiomas (Eldridge 1981). Subcapsular opacities in the lens of juvenile onset develop in about half of all NF2 patients (Kaiser-Kupfer et al. 1989). Identification of germ-line mutations in NF2 patients has revealed that the condition is caused by the germline alteration of one allele of the NF2 gene (Rouleau et al. 1993; Trofatter et al. 1993). In addition, somatic mutations of the NF2 gene are found in both sporadic and familial schwannomas and meningiomas, the most frequent types of nervous system tumors, and they are also frequently observed in mesothelioma (for review, see MacCollin and Gusella 1998). The majority of germ-line and somatic mutations in the NF2 gene, resulting in either a stop codon, a splicing alteration, or a frameshift, leads to the production of a truncated protein. In-frame deletions and missense mutations have also been found, suggesting that alteration of particular functional domains can abolish the function of the NF2 protein. These observations indicate that NF2 is a tumor suppressor gene, although the detailed mechanism by which NF2

\footnotetext{
${ }^{4}$ These authors contributed equally to this work. ${ }^{5}$ Corresponding author.

E-MAIL thomas@cephb.fr; FAX 33153725151.
}

mutation leads to transformation of Schwann cells is largely unknown.

The product of the NF2 gene has been called schwannomin (Rouleau et al. 1993) or merlin (Trofatter et al. 1993). Sequence homologies indicate that schwannomin belongs to the 4.1 superfamily of cytoskeletonassociated proteins and relates more specifically to a subset of this family, consisting of ezrin, radixin, and moesin (the ERM proteins) (Sato et al. 1992). The similarity between schwannomin and ERM proteins suggests that schwannomin may also associate with both membrane and cytoskeletal structures. The ERM homology domain of schwannomin appears to be the main determinant that localizes the protein at the membrane (Deguen et al. 1998). Mutations, which lead to an interstitial deletion in this domain, have been observed both in the germ line of NF2 patients and in sporadic schwannomas, meningiomas, and mesotheliomas. $\mathrm{Mu}-$ tant proteins lacking the exon 2 or 2-3 encoded region lose interaction with the plasma membrane, and are diffusely observed in the cytoplasm (Deguen et al. 1998; Koga et al. 1998). Absence of the exon 2 encoded region results in the loss of ability of schwannomin to interact with four still uncharacterized binding proteins (Takeshima et al. 1994; Nishi et al. 1997). Overexpression of the $\Delta$ exon 2 mutant in cultured cells induces perturbation of cell adhesion (Koga et al. 1998), whereas that of the $\Delta$ exon2-3 mutant in transgenic mice under the 
control of the Schwann cell-specific $P 0$ promoter leads to development of Schwann cell hyperplasia and tumors (Giovannini et al. 1999). Therefore, gross overexpression of mutant NF2 proteins with an altered ERM domain may generally have a dominant oncogenic effect. However, the endogenous expression level of a mutant $N f 2$ allele may not be sufficient to reveal this dominant effect, because inactivation of the second wild-type allele is found in the tumors in NF2 patients and in sporadic schwannomas, meningiomas, and mesotheliomas.

Heterozygous Nf2 mutant mice develop cancer at advanced age, osteosarcomas at a high frequency and fibrosarcoma and hepatocellular carcinoma at an increased, but lower frequency (McClatchey et al. 1998). Nearly all these tumors exhibit loss of the wild-type $N f 2$ allele, indicating that the $N f 2$ gene has a classical tumor suppressor gene function in the progenitor cell of these tumors. However, $N f 2^{+/-}$mice develop neither tumoral nor non-tumoral manifestations of human NF2. Thus, these mice do not represent a phenotypically accurate model for the human NF2 disease.

Homozygous Nf2 mutant murine embryos fail in development at approximately day 7 of gestation, displaying poorly organized extraembryonic ectoderm (McClatchey et al. 1997). This early lethality hinders the phenotypic analysis of mice with Nf2-deficient Schwann cells. To circumvent the embryonic lethality, we generated conditional $N f 2$ knockout mice with restricted biallelic Nf2 mutation in Schwann cells directed by the $P O$ promoter. Here we report the phenotypic characterization of conditional POCre;Nf2 knockout mice and the comparison of their specific features with those observed in NF2 patients.

\section{Results}

Deletion of Nf2 exon 2 leads to functional

impairment of its protein product in the mouse

In our approach to model more closely human hereditary (NF2-related) and sporadic schwannoma in the mouse, we have initially generated three mouse lines carrying different $N f 2$ mutant alleles.

The $N f 2^{\mathrm{KO} 3}$ mutant allele was generated in ES cells by insertion of the IRESLacZ/PGKHyg cassette in Nf2 exon 3 (Fig. 1A). This $N f 2^{\mathrm{KO} 3}$ allele differed from the mutant allele described by McClatchey et al. (1997), here called $N f 2^{\mathrm{KO} 2-3}$. In the latter, the $3^{\prime}$ part of exon 2 up to the $5^{\prime}$ part of intron 3 has been replaced by the selection marker leading to a message that has skipped exons 2 to 4 .

To anticipate a non-intended tumor spectrum by heterozygosity and murine embryonic lethality by homozygosity for the $N f 2^{\mathrm{KO} 3}$ allele, we used the Cre/loxP recombination system of bacteriophage P1 (Sternberg and Hamilton 1981) to generate conditional Nf2 knockout mice. We utilized a two-step strategy (Gu et al. 1994) to generate in parallel ES cell clones carrying either the $N f 2^{\text {flox } 2}$ or $N f 2^{\Delta 2}$ mutant allele (Fig. 1A). The $N f 2^{\Delta 2}$ allele carried an in-frame deletion of exon 2 . Both the $N f 2^{\mathrm{KO} 3}$ and $N f 2^{\Delta 2}$ alleles mimicked two different, naturally oc- curring, human mutant NF2 alleles found in the germ line and allowed us to compare the phenotypic effects of the two in mice. The $N f 2^{\text {flox } 2}$ allele carried an insertion of two loxP sites in the intronic regions flanking exon 2 . In contrast to the $N f 2^{\mathrm{KO} 3}$ and $N f 2^{\Delta 2}$ alleles, this mutant allele retained its function but could be somatically inactivated by Cre-mediated recombination.

Germ line transmission was obtained upon injection of all three types of ES cell clones into blastocysts. The consequence of the three different mutations on $N f 2$ mRNAs produced in brain and sciatic nerves was investigated by RT-PCR analysis and subsequent sequencing of the PCR products (data not shown). The corresponding $\mathrm{Nf} 2$ protein products in brain were analyzed by immunoprecipitation and immunoblotting. When compared to full-length Nf2 protein, very low levels of mutant proteins were detected that were likely to correspond to the $\Delta$ exon3 isoform (in the case of the $N f 2^{\mathrm{KO} 3}$ allele), and to the $\Delta$ exon 2 and $\Delta$ exon2-3 isoforms (in the case of the $N f 2^{\Delta 2}$ allele). No mutant Nf2 protein could be detected in the case of homozygosity for the $N f 2^{\text {flox } 2}$ allele (Fig. 1B).

In contrast to NF2 patients, none of $51 \mathrm{Nf2} 2^{\mathrm{KO} /++}$ and 7 $N f 2^{\Delta 2 /+}$ mice followed up to two years of age developed schwannoma, meningioma, or other manifestations of NF2. Instead, both types of heterozygous Nf2 mutant mice were highly predisposed to the formation of osteomas and well differentiated osteosarcomas showing loss of the $\mathrm{Nf}^{+}$allele (Table 1 ; data not shown). The difference in genetic backgrounds likely applies to the finding of osteomas that were not described by McClatchey et al. (1998). This or the different time windows of the histological analyses may account for the lower frequency of metastases of osteosarcoma (29\%) when compared to the $N f 2^{\mathrm{KO} 2-3 /+}$ mice (95\%). Remarkably, a mesothelioma was found in a single $\mathrm{Nf2} 2^{\mathrm{KO} /+}$ mouse showing loss of the $\mathrm{Nf2}^{+}$allele (Table 1).

Comparable to $N f 2^{\mathrm{KO} 2-3 / \mathrm{KO} 2-3}$ embryos, $N f 2^{\mathrm{KO} 3 / \mathrm{KO} 3}$ and $N f 2^{\Delta 2 / \Delta 2}$ embryos died before E9.5 (data not shown). As expected, $N f 2^{\text {flox } 2 / \text { flox } 2}$ mice were viable and fertile.

\section{Characterization of Cre expression and activity pattern in adult transgenic tissues}

To induce Cre-mediated recombination in Schwann cells of mice carrying $N f 2^{\text {flox2 }}$ alleles, we generated P0Cre transgenic mice. The $1.1 \mathrm{~kb}$ of $5^{\prime}$ flanking sequence of the rat $P O$ gene is sufficient to direct expression of heterologous genes principally to myelinating Schwann cells in vivo (Messing et al. 1992). Schwannoma precursor cells are targeted, because transgenic mice expressing either SV40 large T antigen or the naturally occurring $\Delta$ exon2-3 mutant NF2 protein under the rat $P O$ promoter develop schwannomas (Messing et al. 1994; Giovannini et al. 1999).

Eight independent P0Cre transgenic lines were generated. Mice of all Cre lines were healthy, fertile, and showed no sign of disease. Four lines (P0Cre $\left.e^{\mathrm{A}-\mathrm{D}}\right)$ carried a single integration of the transgene that was transmitted at the expected Mendelian ratios. 
$N f 2$ manifestations in conditional $N f 2$ mutant mice
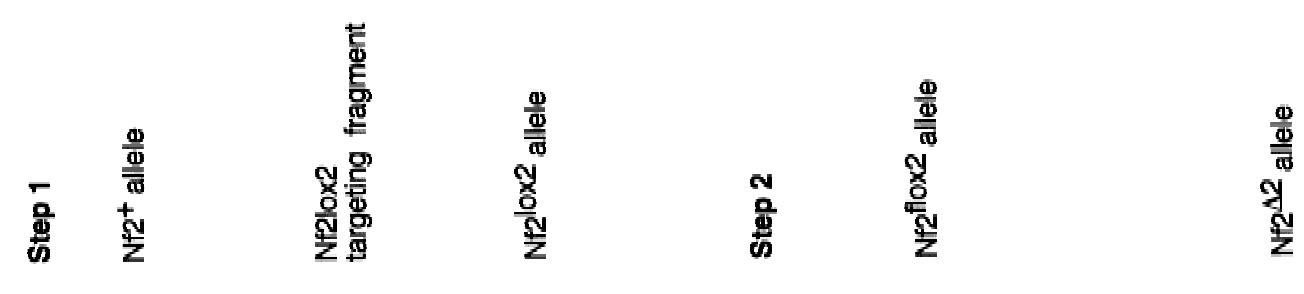

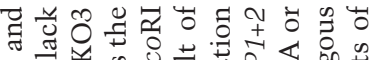

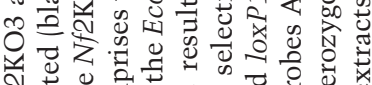

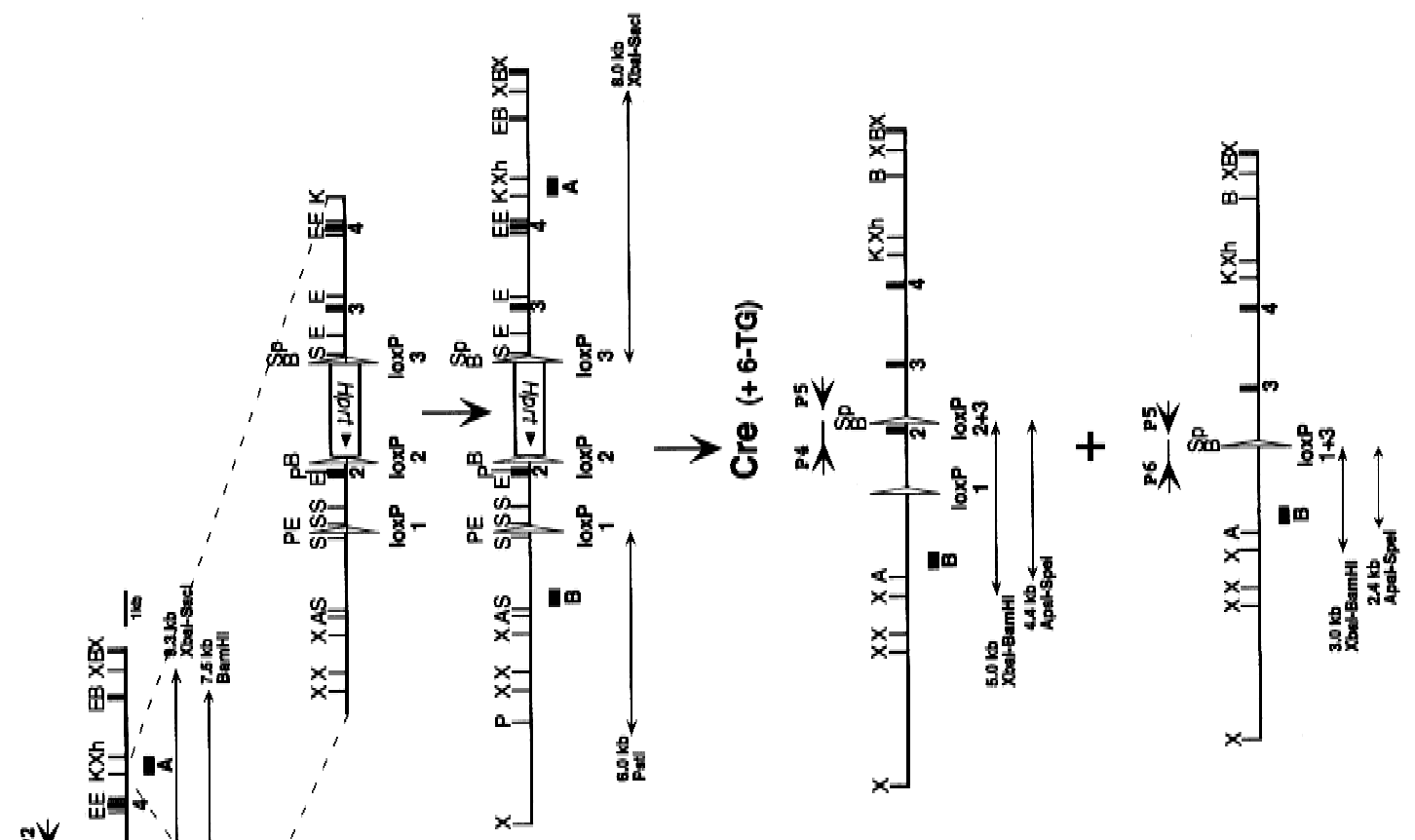

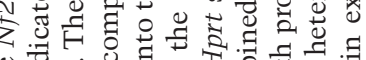

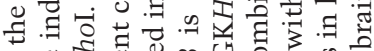

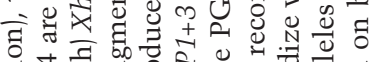

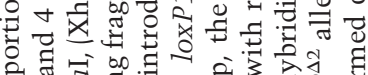
ज.

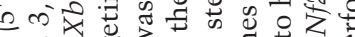

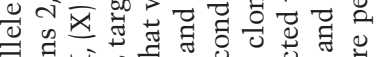

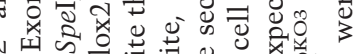
之一

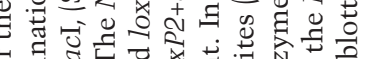

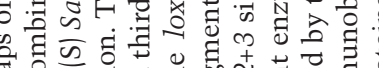

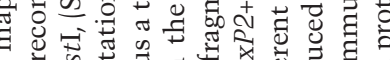

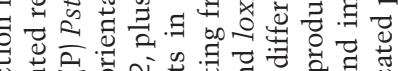

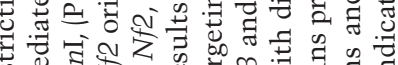

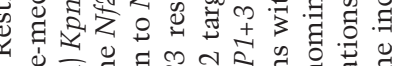

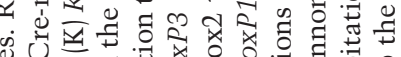

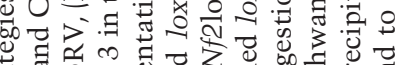

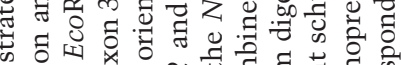

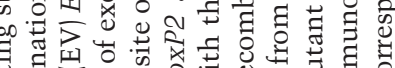

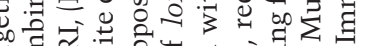

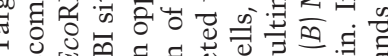

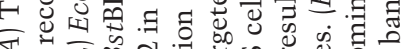

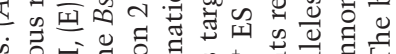
s.

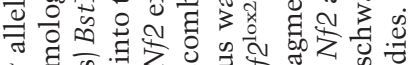

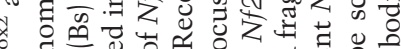

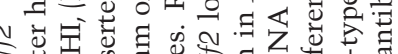

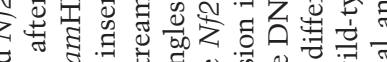

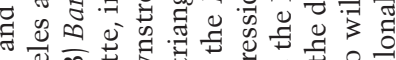

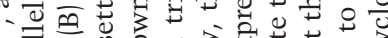

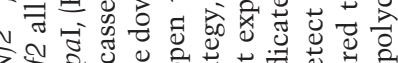

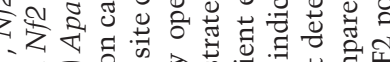
B ब Nit:

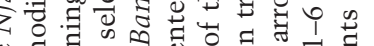

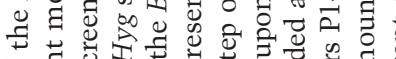

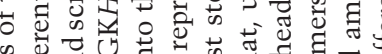

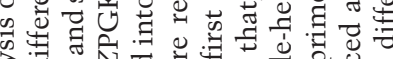

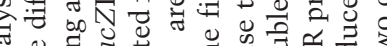

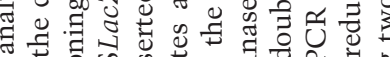

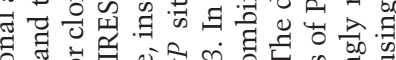

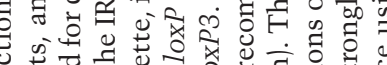

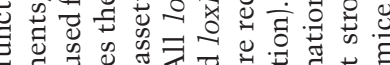

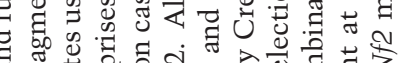

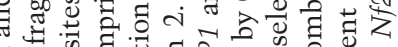

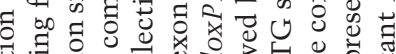

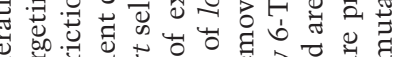

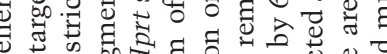
U人,

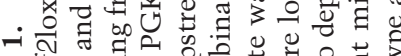

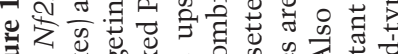

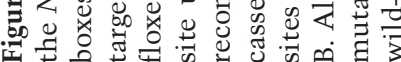


Table 1. Summary of the phenotypic consequences of Nf2 gene mutation in the mouse germline or in P0Cre-expressing cells

\begin{tabular}{|c|c|c|c|c|c|c|c|c|}
\hline \multirow[b]{2}{*}{ Phenotypic abnormality } & \multicolumn{2}{|c|}{$\begin{array}{c}N f 2^{\mathrm{KO} /+} \\
\text { outbred }^{\mathrm{a}}(\mathrm{n}=16)\end{array}$} & \multicolumn{2}{|c|}{$\begin{array}{c}N f 2^{\Delta 2 /+} \\
\text { outbred }^{\mathrm{a}}(\mathrm{n}=7)\end{array}$} & \multicolumn{2}{|c|}{$\begin{array}{c}N f 2^{\text {flox } 2 /+} \\
\text { P0Cre } e^{\mathrm{A}, \mathrm{B}, \mathrm{C}}(\mathrm{n}=16)\end{array}$} & \multicolumn{2}{|c|}{$\begin{array}{c}N f 2^{\text {flox } 2 / \text { flox } 2} \\
\text { POCre }^{\mathrm{C}}(\mathrm{n}=17)\end{array}$} \\
\hline & $\mathrm{n}(\%)$ & $\mathrm{LOH}\left(\mathrm{n}^{\mathrm{b}}\right)$ & $\mathrm{n}(\%)$ & $\mathrm{LOH}\left(\mathrm{n}^{\mathrm{b}}\right)$ & $\mathrm{n}(\%)$ & $\Delta 2\left(\mathrm{n}^{\mathrm{b}}\right)$ & $\mathrm{n}(\%)$ & $\Delta 2\left(\mathrm{n}^{\mathrm{b}}\right)$ \\
\hline Schwann cell hyperplasia & 0 & & 0 & & 0 & & $14(82 \%)$ & \\
\hline Schwannoma & 0 & & 0 & & 0 & & $4(24 \%)$ & $(2 / 2)$ \\
\hline Malignant schwannoma & 0 & & 0 & & 0 & & $2(12 \%)$ & $(2 / 2)$ \\
\hline Neurofibroma & $1(6 \%)$ & n.d. & 0 & & 0 & & 0 & \\
\hline Neurofibrosarcoma & $1^{\mathrm{c}}(6 \%)$ & n.d. & 0 & & 0 & & $1(6 \%)$ & $(1 / 1)$ \\
\hline Stromal sarcoma (LNGFR+) & 0 & & 0 & & 0 & & $5(30 \%)$ & $(5 / 5)$ \\
\hline Osseous metaplasia & 0 & & 0 & & 0 & & $5(30 \%)$ & \\
\hline Osteogenic hyperplasia & $7(44 \%)$ & & 0 & & 0 & & $8(47 \%)$ & \\
\hline Osteoma & $8(50 \%)$ & $(1 / 1)$ & $2(29 \%)$ & n.d. & $1(6 \%)$ & n.d. & $1(6 \%)$ & n.d. \\
\hline Osteosarcoma & $7^{e}(44 \%)$ & $(4 / 4)$ & $3^{\mathrm{f}}(43 \%)$ & $(1 / 1)$ & 0 & & $1(6 \%)$ & n.d. \\
\hline Odontogenic hyperplasia & $1(6 \%)$ & & 0 & & $1(6 \%)$ & & $2(12 \%)$ & \\
\hline Odontoma & 0 & & 0 & & 0 & & $1(6 \%)$ & n.d. \\
\hline Fibrosarcoma & 0 & & $3^{\mathrm{g}}(43 \%)$ & $(1 / 1)$ & 0 & & 0 & \\
\hline Fibroadenoma mammary gland & $2(13 \%)$ & $(1 / 1)$ & 0 & & $1(6 \%)$ & $(0 / 1)$ & $2(12 \%)$ & $(1 / 1)$ \\
\hline Carcino-sarcoma mammary gland & $2(13 \%)$ & $(1 / 1)$ & 0 & & 0 & & 0 & \\
\hline Pap/adenocarcinoma lung & $9(56 \%)$ & $(2 / 3)$ & $1(14 \%)$ & n.d. & $5(31 \%)$ & n.d. & $2^{\mathrm{h}}(12 \%)$ & n.d. \\
\hline Renal tubule hyperplasia & $6(38 \%)$ & & 0 & & 0 & & $9(53 \%)$ & \\
\hline Carcinoma in situ kidney & 0 & & 0 & & 0 & & $3(18 \%)$ & n.d. \\
\hline Anaplastic carcinoma kidney & $1^{\mathrm{i}}(6 \%)$ & $(1 / 1)$ & 0 & & 0 & & 0 & \\
\hline Mesothelioma & $1(6 \%)$ & $(1 / 1)$ & 0 & & 0 & & 0 & \\
\hline Cataract & 0 & & 0 & & 0 & & $3(18 \%)$ & \\
\hline
\end{tabular}

${ }^{\mathrm{a}} \mathrm{FVB} / \mathrm{N} \times 129 / \mathrm{Ola}$

${ }^{b}$ Number of tumors displaying $\mathrm{LOH}$ or $\Delta 2 /$ number of tumors analyzed

${ }^{\mathrm{c}}$ Metastatic to lymph nodes

${ }^{\mathrm{d}}$ Including osteopetrosis and bone exostosis

e 2 of 7 were metastatic to liver $(1 / 1 \mathrm{LOH}+)$

${ }^{\mathrm{f}} 1$ of 3 metastatic to liver (LOH n.d.)

${ }^{g} 1$ of 3 metastatic to lung (LOH n.d.)

${ }^{\mathrm{h}} 1$ of 2 metastatic to kidney/thorax ( $\Delta 2$ n.d.)

${ }^{\mathrm{i} M e t a s t a t i c}$ to liver (LOH n.d.)

n.d., Not determined

An extensive characterization was performed of the pattern of expression and activity of the P0Cre $e^{\mathrm{A}-\mathrm{C}}$ transgenic lines. In all three lines, Cre expression in sciatic nerves was readily detectable by Western blot analysis (Fig. 2A). The levels of expression roughly correlated with the proportions of cells with detectable Cre expression within sciatic nerves, as determined by anti-Cre immunostaining (Fig. 2C,D; data not shown). Next, Cremediated recombination in peripheral nerve cells was evaluated by examination of $\beta$-galactosidase activity in sciatic nerves of mice derived from matings of P0Cre $e^{\mathrm{A}-\mathrm{C}}$ and floxlacZ indicator mice (Akagi et al. 1997). The proportions of blue-stained cells correlated with the Cre expression levels in sciatic nerves of all three lines (Fig. 2E; data not shown). To further characterize the blue-stained cells, we additionally immunostained with anti-Krox-20 antibodies that specifically recognize myelinated Schwann cells (Topilko et al. 1994). Not all blue-stained Schwann cells showed anti-Krox-20 immunopositivity, indicating that Cre-mediated recombination had occurred before commitment to myelinating or nonmyelinating Schwann cells (Fig. 2F).

A PCR-based approach was used to detect the recombination event at the $N f 2^{\text {flox } 2}$ locus in the various tissues of P0Cre $e^{\mathrm{A}-\mathrm{C}}$ conditional Nf2 knockout mice. The 338-bp fragment corresponding to the $N f 2^{\Delta 2}$ allele was amplified principally in the peripheral nerve samples analyzed, thus confirming the specificity of this promoter for the peripheral nervous system. Recombination was also found in the lens, brain cortex, and uterine cervix of all three P0Cre mouse variants, in testis of $\mathrm{POCre}{ }^{\mathrm{A}}$, and in several other tissues of P0Cre ${ }^{\mathrm{B}, \mathrm{C}}$ conditional Nf2 knockout mice (Table 2; data not shown). The efficiency of Cre recombination was assayed by Southern blot analysis. Detection of recombination product was restricted to peripheral nerves, lens, and uterine cervix of all three P0Cre variants (Fig. 2B; Table 2; data not shown). Also, in $\mathrm{P} 0 \mathrm{Cr} \mathrm{e}^{\mathrm{A}}$ conditional $\mathrm{Nf2}$ knockout mice recombination could be detected in brain cortex $(22 \%)$ and testis $(31 \%)$, the latter without transmission of the recombined allele through the germ line.

Because the characteristics of the P0Cre ${ }^{\mathrm{D}}$ line fell within the range of those of the P0Cre $e^{\mathrm{A}-\mathrm{C}}$ lines, all four P0Cre transgenic lines were included in the study of the phenotypic effects on conditional $N f 2$ knockout mice.

The viability of conditional Nf2 knockout mice is dependent on the employed PoCre transgenic line

Two types of conditional Nf2 knockout mice were used 
A
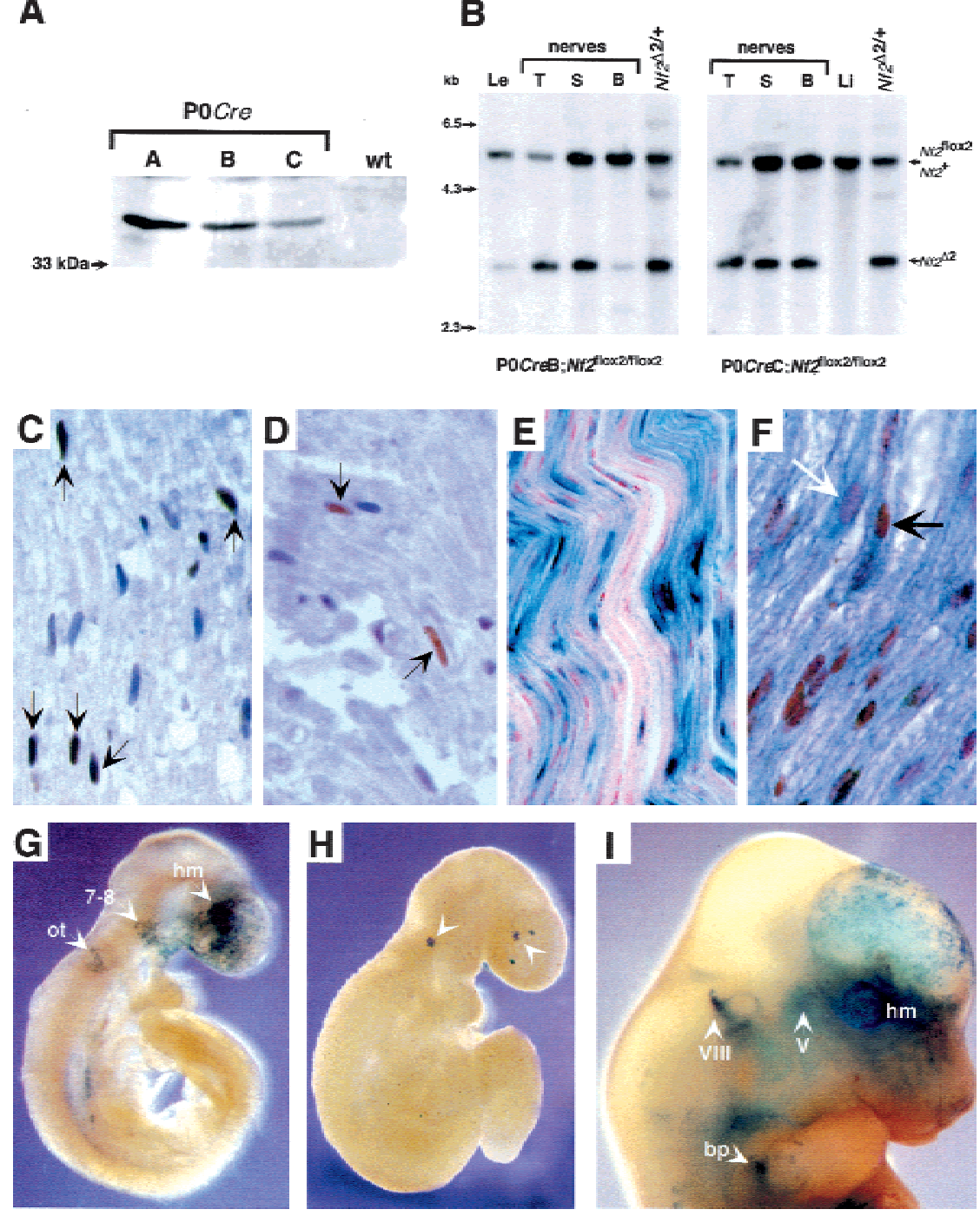
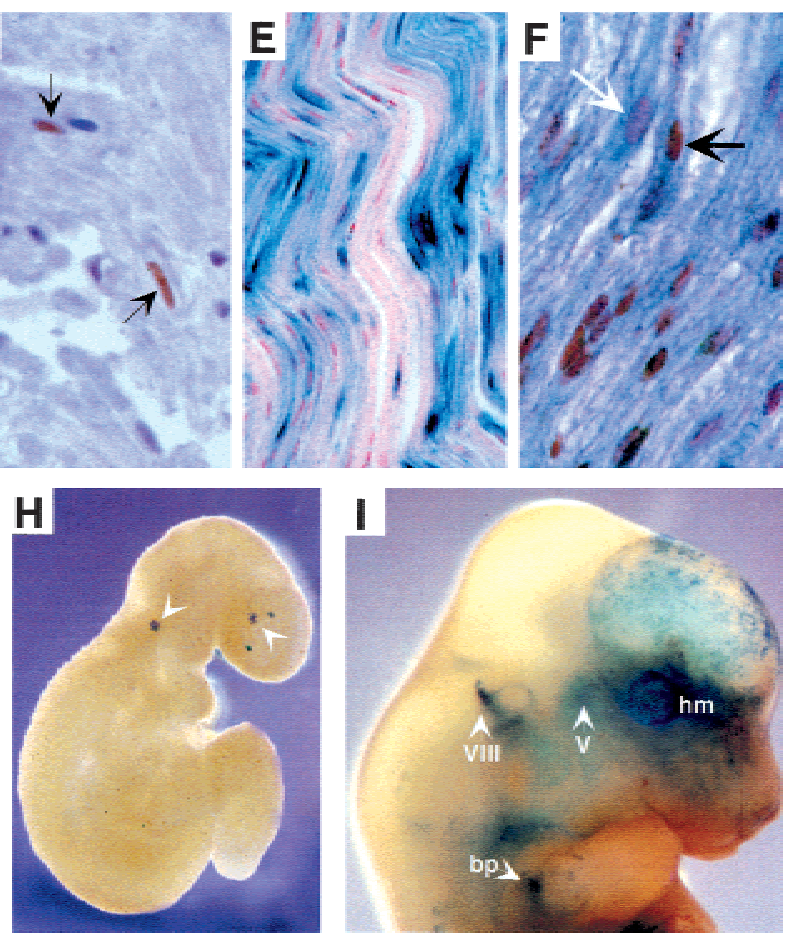

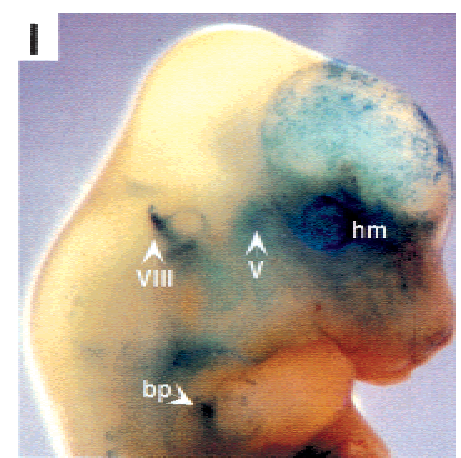

Figure 2. Cre expression and activity pattern in P0Cre transgenic mice. (A) Cre expression in sciatic nerves of adult P0Cre ${ }^{\mathrm{A}-\mathrm{C}}$ transgenic mice. Western blot analysis with rabbit polyclonal anti-Cre antibody. As indicated by a positive immunoreaction at $38 \mathrm{kD}$, the three transgenic lines show Cre expression in sciatic nerves. (B) Cre-mediated deletion in adult mouse tissues. DNA of various tissues of a $\mathrm{POCre} e^{\mathrm{B}} ; \mathrm{Nf}^{\text {flox2/flox2 }}$ and a $\mathrm{P} 0 \mathrm{Cr} e^{\mathrm{C}}$; $N f 2^{\text {flox2/flox2 }}$ mouse (both 3-month-old) was analyzed by Southern blotting (XbaIBamHI digestion, probe B). The $N f 2^{\text {flox } 2}$ allele $(5.0 \mathrm{~kb})$ and $N f 2^{\Delta 2}$ allele $(3.0 \mathrm{~kb})$ can be distinguished by a $\mathrm{XbaI}-\mathrm{BamHI}$ digestion, but the $N f 2^{\text {flox } 2}$ and the $N f 2^{+}$alleles (both $5.0 \mathrm{~kb}$ ) cannot. (T) Trigeminal nerve, (S) sciatic nerve, (B) brachial nerve, (Le) lens, (Li) liver, $\left(N f 2^{\Delta 2 /+}\right)$ tail $\left(1: 1\right.$ ratio of $N f 2^{+}$ and $N f 2^{\Delta 2}$ allele). Arrows on the left side refer to the marker. $(C, D)$ Cre-expressing cells in sciatic nerves of adult $\mathrm{POCre} \mathrm{B}^{\mathrm{B}}(C)$ and $\mathrm{P} 0 \mathrm{Cr} e^{\mathrm{C}}(D)$ transgenic mice, as detected by immunostaining with anti-Cre antibodies. Positive nuclei are indicated by arrows. $(E, F) \beta$-Galactosidase activity in sciatic nerves of adult $\mathrm{P} 0 \mathrm{Cre}{ }^{\mathrm{A}}$;floxlac $Z$ double-transgenic mice, as detected by whole-mount X-gal staining and counterstaining of the sections with nuclear fast red. (E) Sagittal section. (F) Sagittal section additionally immunostained with antiKrox-20 antibodies. A detail is shown of an area with homogeneously blue-stained cells. Recombination occurs in myelinated (Krox- $20^{+}$, black arrow) as well as in non-myelinated (Krox-20-, white arrow) Schwann cells. $(G-I)$ Temporal and spatial expression of lacZ in whole-mount X-galstained P0Cre; floxlacZ double-transgenic mouse embryos. (G) P0Cre ${ }^{\mathrm{A}}$;floxlacZ embryo at E9.5. Lateral view demonstrating that $\beta$-galactosidase activity is mostly observed in the area of the neural crest cell migration: head mesenchyme, ventral cranio-facial area (hm), otocyst (ot), and facio-acoustic neural crest complex (7-8). (H) P0Cre ${ }^{\mathrm{C}}$;floxlacZ embryo at E9.5. Lateral view demonstrating scattered areas of weak $\beta$-galactosidase activity (arrows). (I) P0Cre ${ }^{\mathrm{A}}$;floxlacZ embryo at E12.5. Lateral view demonstrating $\beta$-galactosidase activity in the frontonasal region of the head mesenchyme (hm), ganglia of the VIIIth (VIII) and Vth (V) cranial nerves, and brachial plexus (bp). Magnification, (CF) 40x.

that differed by the number of floxed alleles. $\mathrm{POCre} ; \mathrm{Nf2}{ }^{\mathrm{KO} 3 / \text { flox2 }}$ mice, that required a single recombination event for biallelic Nf2 inactivation, might have a higher tumor incidence in the case of a limiting P0Cre recombination efficiency than $\mathrm{P} 0 \mathrm{Cre} ; \mathrm{Nf2} 2^{\text {flox } 2 / \text { flox } 2}$ mice. Also, in $\mathrm{POCre} ; \mathrm{Nf2}^{\mathrm{KO} 3 / \mathrm{flox} 2}$ mice it would be possible to determine the extent of biallelic loss of Nf2 function, because the (recombined) $\mathrm{Nf}^{\text {flox } 2}$ allele could be distinguished from the inactivated $\mathrm{Nf}^{\mathrm{KO}}{ }^{\mathrm{KO}}$ allele.

$\mathrm{POCre} ; \mathrm{Nf}^{\text {flox2/flox2 }}$ and $\mathrm{POCre} ; \mathrm{Nf2} 2^{\mathrm{KO} 3 / \text { flox2 }}$ mice were monitored closely over a period of 24 months. $\mathrm{P} 0 \mathrm{Cr} e^{\mathrm{A}}{ }_{i} N f 2^{\text {flox } 2 / \text { flox } 2}$ mice were viable, although obtained at a significantly reduced rate $(p<0.005$; data not shown) and not fertile, whereas the very few $\mathrm{POCre}{ }^{\mathrm{A}}{ }_{i} \mathrm{Nf2} 2^{\mathrm{KO} 3 / \mathrm{flox} 2}$ animals died before weaning. $\mathrm{POCr} e^{\mathrm{A}} ; \mathrm{Nf2} 2^{\text {flox } 2 / \text { flox } 2}$ mice were reduced in size and weight compared with their $N f 2^{\text {flox } 2 / \text { flox } 2}$ littermates, the size-difference becoming apparent at the time of transition from liquid to solid diet. Histological examination of these mice at 17 and 19 days of age revealed retarded or absent molar eruption (data not shown). A number of these animals could be rescued by an additional porridge diet before weaning. POCre $e^{\mathrm{B}, \mathrm{C}}$ conditional knockout mice were viable. However, in contrast to the $\mathrm{P} 0 \mathrm{Cre} e^{\mathrm{C}}$ variant, $\mathrm{POCre} e^{\mathrm{B}}$ conditional knockout mice were obtained at a slightly reduced rate (data not shown). These mice showed a similar but smaller reduction in size and weight approaching weaning compared to the P0Cre $e^{\mathrm{A}}$ variant.

The percentages of survival of P0Cre $e^{\mathrm{A}, \mathrm{B}, \mathrm{D}} ; \mathrm{Nf}^{\text {flox } 2 / \text { flox2 }}$ mice were significantly reduced compared to that of $N f 2^{\text {flox2/flox2 }}$ animals (Kaplan-Meier Test: $p<0.0001$ ), 
Table 2. Cre-mediated recombination in tissues of POCre; $\mathrm{Nf}^{\text {flox2/flox2 }}$ mice

\begin{tabular}{|c|c|c|c|c|}
\hline & \multicolumn{2}{|c|}{ POCre ${ }^{\mathrm{B}}$} & \multicolumn{2}{|c|}{$\mathrm{P} 0 \mathrm{Cr} e^{\mathrm{C}}$} \\
\hline & PCR & SB & PCR & SB \\
\hline Brain cortex & + & $0 \%$ & + & $0 \%$ \\
\hline Cerebellum & - & $0 \%$ & - & $0 \%$ \\
\hline Brain stem & - & $0 \%$ & \pm & $0 \%$ \\
\hline Spinal cord & - & $0 \%$ & \pm & $0 \%$ \\
\hline Optic nerve & +++ & n.d. & ++ & n.d. \\
\hline Trigeminal nerve & +++ & $60 \%$ & +++ & $54 \%$ \\
\hline Brachial plexus & +++ & $14 \%$ & +++ & $40 \%$ \\
\hline Sciatic nerve & +++ & $45 \%$ & +++ & $40 \%$ \\
\hline Lens & ++ & $21 \%$ & ++ & $9 \%$ \\
\hline Pituitary gland & \pm & $0 \%$ & \pm & $0 \%$ \\
\hline Lung & - & $0 \%$ & + & $0 \%$ \\
\hline Heart & + & $0 \%$ & + & $0 \%$ \\
\hline Kidney & + & $0 \%$ & + & $0 \%$ \\
\hline Thymus & + & $0 \%$ & \pm & $0 \%$ \\
\hline Spleen & - & n.d. & - & n.d. \\
\hline Liver & - & $0 \%$ & - & $0 \%$ \\
\hline Colon & + & $0 \%$ & \pm & $0 \%$ \\
\hline Muscle & \pm & $0 \%$ & \pm & $0 \%$ \\
\hline Testis & - & $0 \%$ & - & $0 \%$ \\
\hline Uterus body & + & $0 \%$ & + & $0 \%$ \\
\hline Uterus cervix & ++ & $19 \%$ & ++ & $5 \%$ \\
\hline
\end{tabular}

For each P0Cre line, tissues were analyzed of two mice (one female and one male mouse). The $N f 2^{\text {flox } 2}$ and $N f 2^{\Delta 2}$ alleles were detected in independent PCR reactions using primers $\mathrm{P} 4$ and $\mathrm{P} 5$, and $\mathrm{P} 5$ and $\mathrm{P} 6$, respectively [recombination-efficiency estimates varied between (-) to $(+++)]$. For Southern blot analysis $(\mathrm{SB})$, estimates of recombination efficiency were obtained from phosphorimage quantification of recombined to non-recombined bands.

n.d., Not determined.

whereas the percentages of survival of $\mathrm{POCre}^{\mathrm{C}}$; $N f 2^{\text {flox } 2 / \text { flox } 2}$ and $\mathrm{POCr} e^{\mathrm{A}, \mathrm{B}} ; \mathrm{Nf2} 2^{\text {flox } 2 /+}$ mice were only borderline and not significantly different from that of $N f 2^{\text {flox } 2 / \text { flox } 2}$ animals $(p=0.044, p=0.051$, and $p=0.851$, respectively) (Fig. 3A; data not shown). Also, significant reductions in percentage of survival were found in $\mathrm{P} 0 \mathrm{Cr} e^{\mathrm{B}-\mathrm{D}} ; \mathrm{Nf} 2^{\mathrm{KO} 3 / \text { flox2 }}$ mice compared to $N f 2^{\mathrm{KO} 3 / \text { flox } 2}$ mice $(p<0.0001)$ (data not shown). In addition to the retarded or absent molar eruption, severe otitis media reduced the viability of $\mathrm{P} 0 \mathrm{Cr} e^{\mathrm{A}, \mathrm{B}} ; \mathrm{Nf} 2^{\text {flox2/flox2 }}$ and $\mathrm{P} 0 \mathrm{Cr} e^{\mathrm{B}} ; \mathrm{Nf2} 2^{\mathrm{KO} / \text { flox2 }}$ mice, a pathological feature found in $\sim 50 \%$ of the mice that died within the first year. In these mice, size and weight reduction and susceptibility to middle ear infection were probably the result of the frequently observed cranio-facial abnormalities.

\section{Biallelic Nf2 mutation is rate-limiting for murine schwannoma development}

P0Cre; $N f 2^{\text {flox } 2 / \text { flox2 }}$ mice developed both benign and malignant Schwann cell tumors later in life (from 10 months on). Schwannomas were found in 4 of 17 (24\%) of POCre ${ }^{\mathrm{C}}$; $N \mathrm{f}^{\text {flox } 2 / \text { flox } 2}$ mice, whereas malignant schwannomas were observed in 2 of $17(12 \%)$ of these animals
(Table 1). Also, a neurofibrosarcoma was seen in 1 of 17 $(6 \%)$ of $\mathrm{P} 0 \mathrm{Cre}{ }^{\mathrm{C}}{ }_{;} \mathrm{Nf} \mathrm{f}^{\text {flox } 2 / \text { flox2 }}$ mice (Table 1). Similarly, $\mathrm{P} 0 \mathrm{Cre} \mathrm{B}^{\mathrm{B}, \mathrm{D}} ; \mathrm{Nf2} 2^{\text {flox } 2 / \text { flox } 2}$ mice developed Schwann cell tumors, 1 of $27(4 \%)$ and 2 of $3(66 \%)$, respectively (data not shown). All Schwann cell tumors that were tested by Southern blot analysis showed deletion of exon 2 (10 of 10; Table 1; Fig. 3B). No Schwann cell tumors were found

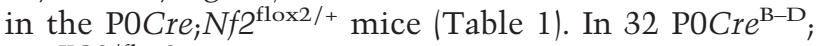
$N f 2^{\mathrm{KO} 3 / \text { flox2 }}$ mice, the Schwann cell tumor pattern was essentially the same, although the incidence was lower due to the reduced survival of P0Cre; $\mathrm{Nf}^{\mathrm{KO} / \text { flox2 }}$ mice as described above (data not shown). Also in this type of mice, the two Schwann cell tumors analyzed showed deletion of exon 2. No loss of the $N f 2^{\text {flox } 2}$ allele was seen (Fig. 3C; data not shown). Thus, Schwann cell tumorigenesis in both types of conditional Nf2 knockout mice (i.e., KO3/flox 2 or flox $2 /$ flox2) was dependent on the recombination of the $N f 2^{\text {flox } 2}$ allele(s). Moreover, inactivation by Cre-mediated recombination of both $N f 2^{\text {flox } 2}$ alleles appeared to be as efficient as that of a single $N f 2^{\text {flox2 }}$ allele in combination with the $N f 2^{\mathrm{KO} 3}$ allele. The 13 peripheral nerve tumors in both types of conditional knockout mice were found at various locations: uterus (4), spinal ganglion (1), skin (1), submandibular region (1), retroperitoneum (1), stomach (1) (Fig. 4A), small intestine (1), colon/rectum (1), bladder (1), and foreleg (1). Their Schwann cell origin was substantiated by immunoreactivity with the $75 \mathrm{kD}$ low affinity nerve growth factor receptor (LNGFR; 100\%; 13 of 13), S-100 protein $(38 \%$; 5 of 13$)$, and glial fibrillary acidic protein (GFAP; $50 \%$; 6 of 12) (data not shown). No Cre expression was detectable, as analyzed by immunostaining of 4 Schwann cell tumors (data not shown). Ultrastructural examination of one uterine tumor showed a mixture of predominantly Schwann cells with thin cytoplasmic processes and basal membrane, and some fibroblasts, perineurial cells, and smooth muscle cells (Fig. 4B). These are diagnostic features of human schwannomas (Erlandson and Woodruff 1982). The Schwann cell tumors in the uterus arose mainly in the corpus uteri. Additionally, we found less differentiated tumors mostly resembling stromal sarcomas in the uterus horns, pelvis, and bladder, all showing deletion of exon 2 and immunocharacteristics similar to those of the Schwann cell tumors (Table 1; data not shown).

In human NF2 patients, Schwann cell hyperplasia (schwannosis) is a common finding in the spinal roots and peripheral nerves, most likely representing a precursor lesion with the potential for progression into schwannoma (Wiestler and Radner 1994). Similarly, Schwann cell hyperplasia was found at high frequency in both types of POCre $e^{\mathrm{B}-\mathrm{D}} ; \mathrm{Nf2} 2^{\mathrm{KO} 3 / \text { flox2 }}$ mice (19 of $32 ; 59 \%$ ) and P0Cre $e^{\mathrm{A}-\mathrm{D}} ; \mathrm{Nf} 2^{\text {flox } 2 / \text { flox } 2}$ mice $(45$ of $51 ; 88 \%)$. This phenomenon was absent in the $16 \mathrm{POCre}^{\mathrm{A}-\mathrm{C}} ; \mathrm{Nf} 2^{\text {flox } 2 /+}$, $25 \mathrm{Nf} 2^{\mathrm{KO} /+}$, and $7 \mathrm{Nf2} 2^{\Delta 2 /+}$ mice (Table 1). Therefore, Schwann cell hyperplasia was specifically observed concomitant with complete loss of $\mathrm{N} f 2$ function, indicating that biallelic Nf2 mutation promotes this phenotypic expression. Basal and spinal ganglia were the predominant sites of the often diffuse form of Schwann cell hyperpla- 


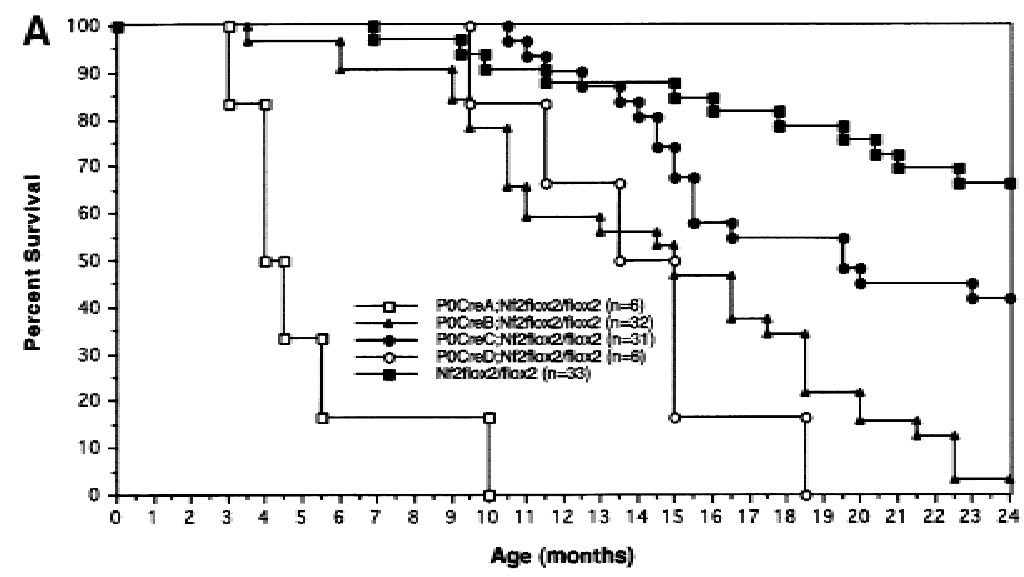

B
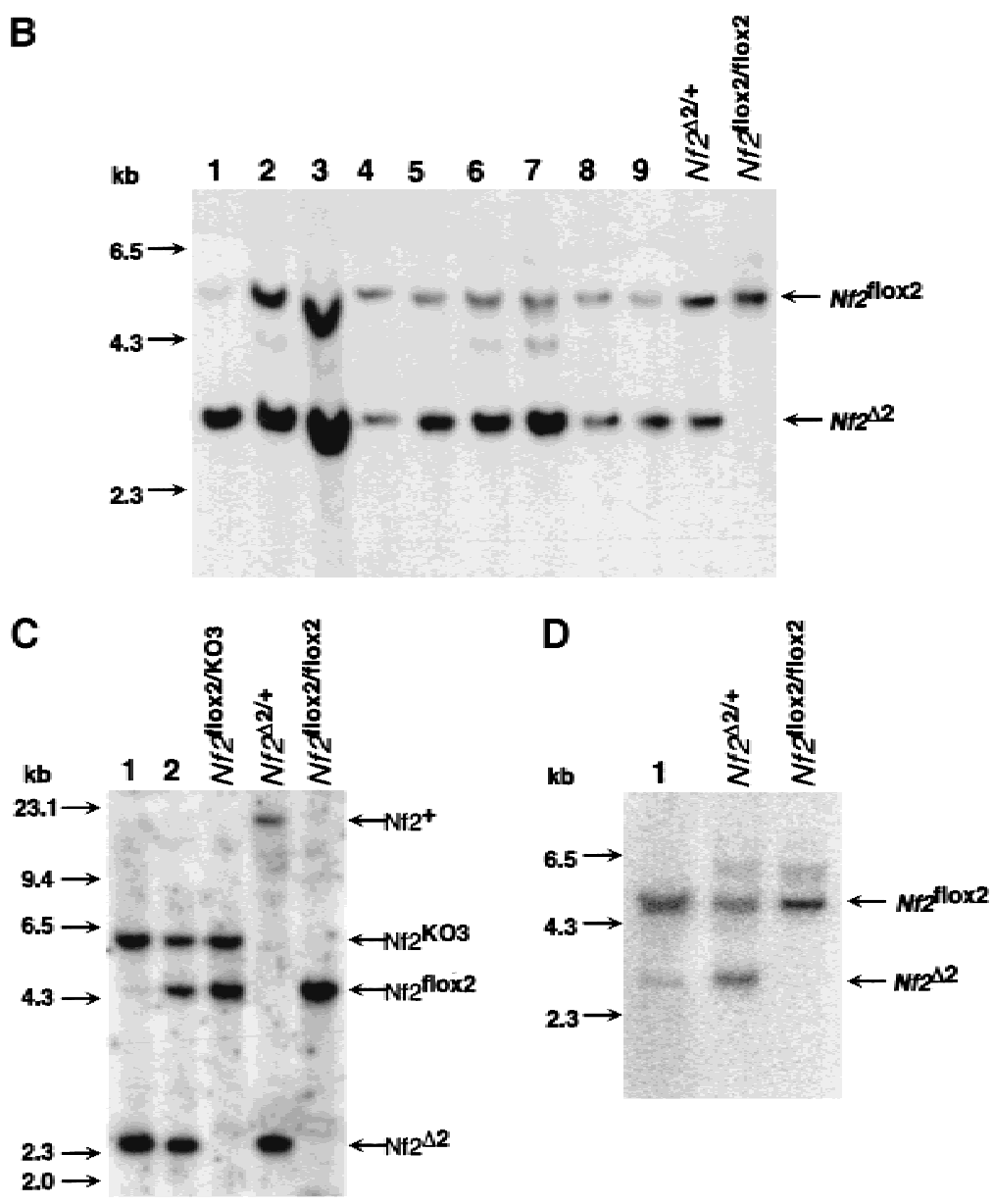

sia (Fig. 4C,D). Remarkably, the distal peripheral nerves seldom showed Schwann cell abnormalities, except for $\mathrm{POCre}{ }^{\mathrm{A}}{ }_{i} N f 2^{\text {flox } 2 / \text { flox } 2}$ mice where hyperplasia/hypertrophy was seen in 2 of 4 young animals (4 months of mean age) and in one pup of 17 days of age (Fig. 4E). Moreover, one subcutaneous Schwann cell nodule and one hamartoma of the olfactory bulb composed of Schwann and neural cells was found in two $\mathrm{P} 0 \mathrm{Cr} e^{\mathrm{A}} ; \mathrm{Nf}^{\mathrm{KO} 3 / \text { flox2 }}$ pups of 17 and 19 days of age, respectively. Because $\mathrm{POCre}{ }^{\mathrm{A}} ; \mathrm{Nf2}{ }^{\mathrm{KO} 3 / \text { flox2 }}$ mice died before weaning and
Figure 3. Survival of conditional $N f 2$ knockout mice and DNA analysis of tumors. (A) The viability of $\mathrm{P} 0 \mathrm{Cre} ; \mathrm{Nf} 2^{\text {flox } 2 / \text { flox } 2}$ mice correlates with the expression level of Cre. Survival curves of $\mathrm{POCre}{ }^{\mathrm{A}-\mathrm{D}} ; \mathrm{Nf} 2^{\text {flox } 2 / \text { flox } 2}$ and $\mathrm{Nf2} 2^{\text {flox } 2 / \text { flox } 2}$ mice over a period of 24 months (numbers of considered moribund plus dead animals in brackets). (B) Tumors of P0Cre; $\mathrm{Nf2}^{\text {flox2/flox } 2}$ mice show Cre-mediated Nf2 gene inactivation. Southern blot analysis (probe B) of XbaI-BamHI-digested DNA of nine representative tumors (lanes 19). The bands corresponding to the $N f 2^{\text {flox2 }}$ and $N f 2^{\Delta 2}$ allele, and those referring to the marker (left) are indicated by arrows. (C) Tumors of POCre; Nf2 $2^{\mathrm{KO} / \text { flox } 2}$ mice show Nf2 gene inactivation. Southern blot analysis (probe B) of ApaI-SpeI-digested DNA of a neurofibrosarcoma in the uterus (lane 1) and the corresponding metastasis in a lymph node (lane 2). The primary tumor and the metastasis showed Cre-mediated excision of the floxed exon 2: The intensity of the $N f 2^{\Delta 2}$ band inversely correlates with that of the $N f 2^{\text {flox } 2}$ band, indicating that no loss of the $N f 2^{\Delta 2}$ allele has occurred. All different $N f 2$ alleles can be distinguished by ApaI-SpeI digestion, as indicated in Fig. 1A $\left(\mathrm{Nf2}^{+}>13 \mathrm{~kb}\right) .(D)$ Osseous metaplasia in the lung of a P0Cre; $N f 2^{\text {flox } 2 / \text { flox } 2}$ mouse shows Cre-mediated Nf2 gene inactivation. Southern blot analysis (probe B) of $\mathrm{XbaI}$-BamHI-digested DNA obtained from the lesion shown in Fig. 5C (lane 1). The bands corresponding to the $N f 2^{\text {flox } 2}$ and $N f 2^{\Delta 2}$ allele are indicated by arrows. 

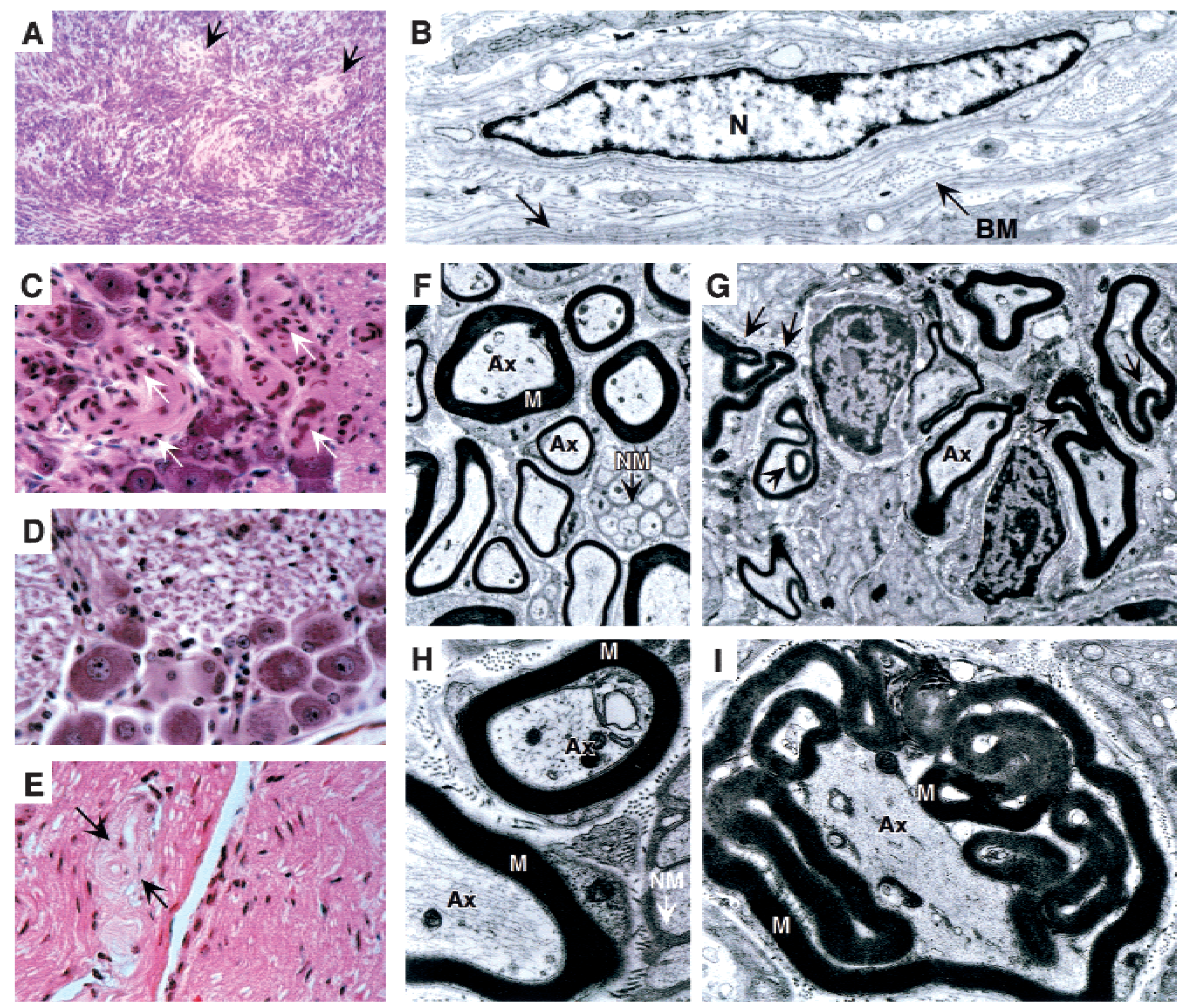

Figure 4. Histological analysis of phenotypic abnormalities in P0Cre; $N f 2^{\text {flox2/flox } 2}$ mice. $(A, B)$ Schwann cell tumors. $(A)$ P0Cre $e^{\mathrm{C}}$ line. Spindle cell tumor located on the external side of the esophageal-gastric junction. The tumor shows focal Schwann cell characteristics such as Antoni A type palisading (arrows) and primitive Verocay body formation. $(E)$ P0Cre $e^{\mathrm{C}}$ line. Ultrastructural examination of a uterine schwannoma showed Schwann cells with long, thin cytoplasmic processes (arrow) and variantly coated by a basement membrane (BM). Schwann cell nucleus (N). (C-I) Schwann cell hyperplasia. $(C, D)$ P0Cre ${ }^{\mathrm{B}}$ line. $(C)$ Schwann cell hyperplasia (arrows) in a trigeminal ganglion and $(D)$ normal trigeminal ganglion of a wild-type littermate. $(E)$ P0Cre ${ }^{\mathrm{A}}$ line. Schwann cell hyperplasia/ atrophy (arrows) in a sciatic nerve. $(F-I)$ Ultrastructure of the sciatic nerves of a $(F, H) N f 2^{\text {flox } 2 / f l o x 2}$ and $(G, I)$ P0Cre ${ }^{\mathrm{A}} ; N f 2^{\text {flox } 2 / \text { flox }^{2}}$ mouse. $(F, H)$ Normally myelinated Schwann cell (M) surrounding the axoplasm (Ax). Non-myelinated Schwann cells (NM) are also shown. $(G, I)$ Myelin sheaths herniating and looping into the central axonal region of the nerve. $(A, C-E)$ H\&E stains. Magnification in $(A) 200 \times$; (B) 4400×; (C-E) 630x; (F) 3000×; (G) 4400x; (H) 12000×; (I) 10,400×.

herniated and looped into the central axonal region of the nerve (Fig. 4G,I). Ultrastructural analysis of sciatic

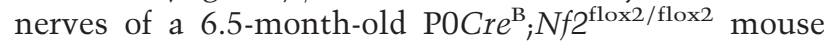
showed relatively normal features with occasional whorls of thin cytoplasmic processes (data not shown). The Schwann cell abnormality in the sciatic nerve might be a result of hyperplasia and/or hypertrophy, the latter as a result of disturbed myelinization.

Taken together, these results indicate that mutation of the wild-type Nf2 allele in both the germ-line and conditional heterozygous $N f 2$ knockout mice is the rate- limiting step not only for Schwann cell tumorigenesis but also for Schwann cell hyperplasia.

P0 promoter-directed biallelic $\mathrm{Nf} 2$ mutation leads to tumors in tissues with neural crest-derived components

In addition to the Schwann cell tumors, three osteomas and one osteosarcoma were found in 4 of $51(8 \%)$ P0Cre; $N f 2^{\text {flox } 2 / \text { flox } 2}$ mice, whereas one osteoma was found in $16(6 \%)$ POCre; $\mathrm{Nf}^{\text {flox } 2 /+}$ mice (Table 1; data not shown). Two osteomas arose in the craniofacial bones, 
one in the main nerve of the mandible (Fig. 5A), whereas one osteosarcoma was detected in the lung without indication of a primary bone tumor elsewhere. Because the tumors in the P0Cre; $N f 2^{\text {flox } 2 / \text { flox } 2}$ mice could arise solely in the P0-expressing cell lineage, the finding of bone tumors suggests that this included osteoblast precursor cells. Although P0 is principally expressed in myelinating Schwann cells, expression has been detected long before myelination in a subpopulation of migrating neural crest cells, including the Schwann cell lineage, irrespective of whether they will myelinate or not (Lee et al. 1997). Recently, the temporal and spatial pattern of this $P O$ promoter activity was characterized in similar PO-Cre transgenic mice using CAG-CAT-Z indicator mice (Yamauchi et al. 1999). Cre recombination was found as early as embryonic day 9 (E9.0) and colocalized with the distribution pattern of neural crest cells, that is, by its presence in the ventral craniofacial mesenchyme of the pharyngeal arches and the frontonasal region, in the spinal dorsal root ganglia, sympathetic nervous system, and enteric nervous system (Yamauchi et al. 1999). To verify the occurrence of Cre recombination in neural crest-derived cells of P0Cre transgenic mice, we examined $\beta$-galactosidase activity in embryos derived from matings of P0Cre $e^{\mathrm{A}-\mathrm{C}}$ and floxlacZ mice. Comparable to Yamauchi et al. (1999), lacZ expression was already apparent at E9.5 when Schwann cells are not yet formed. Indeed, the expression at E9.5, E10.5, and E12.5 colocalized with the neural crest cell distribution pattern as described by Yamauchi et al. (1999) (Fig. 2G-I; data not shown). However, the level of Cre expression at these embryonic stages appeared too low to detect by immunostaining (data not shown). The expressing mesenchymal cells, forming the so-called mesectoderm, yield most of the skull bones and facial skeleton (Couly et al. 1993). Also, the cephalic neural crest has an odontogenic potential (Lumsden 1988) and a role of the neuroectoderm in organogenesis of the kidney has been suggested (Willis 1958). This might well explain the development in
P0Cre; $N f 2^{\text {flox } 2 / \text { flox } 2}$ mice of odontomas (Fig. 5B) and odontosarcomas $(3$ of $51 ; 6 \%)$, as well as carcinomas in situ of the kidney (5 of $51 ; 10 \%$ ) (Table 1 ; data not shown). These tumors were only microscopically detectable and not available for DNA analysis. However, they were neither found in the P0Cre; $N f 2^{\text {flox } 2 /+}$ mice nor in the $N f 2^{\mathrm{KO} /+}$ mice suggesting that, like in Schwann cells, loss of the remaining $\mathrm{Nf2}^{+}$allele is rate limiting for tumor formation in two other neural crest-derived cell types. This was further supported by the finding of one odontoma and one carcinoma in situ of the kidney in P0Cre; $N f 2^{\mathrm{KO} 3 / \text { flox2 }}$ mice. However, it can not be excluded that tumor outgrowth of the odontogenic epithelium was caused by the maxillary petrosis. P0Cre $; \mathrm{Nf} 2^{\mathrm{KO} 3 / \text { flox2 }}$ mice developed also one osteoma and two osteosarcomas (3 of $32 ; 9 \%)$, probably due to the $N f 2^{\mathrm{KO} 3}$ allele, as indicated by the loss of the $N f 2^{\text {flox } 2}$ allele in one analyzed osteosarcoma (data not shown) (the low frequencies resulted from the reduced viability of the P0Cre; $N f 2^{\mathrm{KO} 3 / \text { flox } 2}$ mice as discussed above).

Interestingly, in addition to the mesothelioma showing $\mathrm{LOH}$ for $N f 2$ in the $N f 2^{\mathrm{KO} /++}$ mice, we found one mesothelioma in the P0Cre; $N f 2^{\mathrm{KO} / \text { flox } 2}$ mice. Also, this tumor arose due to the presence of the $N f 2^{\mathrm{KO} 3}$ allele, because recombination of the $N f 2^{\text {flox } 2}$ allele was not observed by PCR (data not shown). Although this tumor type has never been reported in NF2 patients, a high frequency of biallelic NF2 inactivation has been described in its sporadic form (Bianchi et al. 1995; Sekido et al. 1995). In contrast to Schwann cell hyperplasia, osteoblastic, odontoblastic, and renal tubular cell hyperplasia were seen in $N f 2^{\mathrm{KO} 3 /+}$ mice besides P0Cre; $N f 2^{\text {flox } 2 / \text { flox } 2}$ and $\mathrm{POCre} ; \mathrm{Nf}_{2} \mathrm{KO} / \mathrm{flox} 2$ animals, whereas it was absent in $\mathrm{P} 0 \mathrm{Cr} e_{;} \mathrm{Nf2} \mathrm{flox}^{\mathrm{flo} /+}$ mice (Table 1 ). This suggests that activation of the $P O$ promoter occurred late in the differentiation process toward final osteoblasts, odontoblasts, and renal tubular cells, leading to a lower frequency of spontaneous loss of the wild-type allele when compared to the frequency in $\mathrm{Nf2} 2^{\mathrm{KO} /+}$ mice.
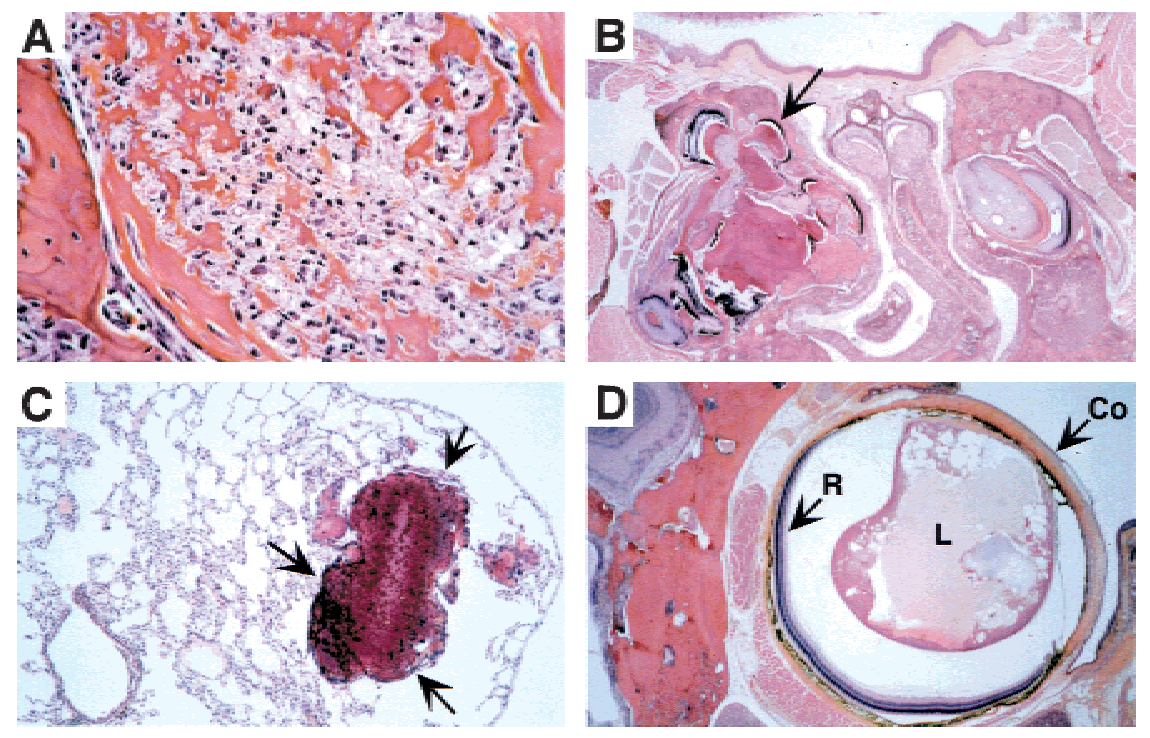

Figure 5. $P 0$-specific conditional homozygous Nf2 knockout mice develop characteristics of neurocristopathy. (A) Osteoma developing within the main mandibular nerve. (B) Odontoma of upper incisor, deforming the maxilla and nasal septum. Many foci of "ectopic" enamel production are seen (arrow) as well as osteopetrotic processes in the contralateral maxilla. (C) Osseous metaplasia (arrow) in the lung. $(D)$ Cataract in a mouse showing normal cranio-facial development. Note the small, irregularly shaped lens (L) and the attachment of the lens to the cornea (Co). Retina (R). H\&E stains. Magnification, $(A) 400 x_{;}(B, D) 25 x_{;}(C) 100 \times$. 
Intriguingly, two non-neoplastic features of NF2 were also observed in Nf2 mutant mice. Intracranial calcifications have been noted frequently in neuroimaging studies of NF2 patients but the histopathogenesis of these deposits has remained unclear (Mayfrank et al. 1990). In both $N f 2^{\mathrm{KO} /+}$ (inbred) and conditional $N f 2$ knockout mice, osseous metaplasia was predominantly found in the lung (at frequencies ranging between 24\% and 67\%), and also in the brain, kidney, and nasal mucosa (Table 1; Fig. 5C; data not shown). Apparently, the osseous metaplasia was dependent on biallelic loss of $N f 2$, because these lesions were absent in the P0Cre; $N f 2^{\text {flox } 2 /+}$ mice and deletion of exon 2 could be detected in one lesion by Southern blot analysis (Table 1; Fig. 3D). Cataract in the lens, in man indicative of NF2 evaluation, was found in 27 of $46(59 \%)$ of the POCre $e^{\mathrm{B}}$ and 4 of $28(14 \%)$ of the P0Cre $e^{\mathrm{C}}$ conditional knockout mice, occurring in the bilateral form in half of the cases (Table 1; Fig. 5D; data not shown). Upon examination of lens DNA of P0Cre $e^{\mathrm{A}-\mathrm{C}}$ conditional Nf2 knockout mice by Southern blot analysis, deletion of exon 2 could clearly be detected (Table 2; Fig. 2B; data not shown). Cataract was not found in 16 POCre; $N f 2^{\text {flox } 2 /+}$ mice, strongly suggesting that development of cataract was dependent on biallelic loss of $N f 2$.

In conclusion, our results indicate that $\mathrm{PO}$-specific conditional Nf2 knockout mice develop various characteristics of neurocristopathy.

\section{Discussion}

In contrast to human NF2 patients, mice hemizygous for the Nf2 gene do not develop schwannoma, the hallmark feature of neurofibromatosis type 2 . The phenotypic consequences of two Nf2 mutations described here (leading to either a $\Delta$ exon 2 or a $\Delta$ exon3 splice product) show three similarities with those of the different Nf2 mutation leading to a $\Delta$ exon2-4 splice product described by McClatchey et al. (1997, 1998). Firstly, homozygosity for each mutant allele results in embryonic lethality. Secondly, heterozygosity for each mutant allele affects the osteoblast leading to a high incidence of bone tumors showing loss of the wild-type Nf2 allele. Our data indicate that both exon 2 and exon 3 carry sequences that are essential for Nf2 function. Thirdly, mice heterozygous for each mutant allele do not show features of human NF2. In particular they demonstrate a tumor spectrum that differs entirely from that observed in NF2 patients. Therefore, these animals cannot serve as a model for the cognate human genetic disease.

Several factors, reviewed by Jacks (1996), may explain the lack of overlap of the tumor spectrum in humans and mice heterozygous for a homologous tumor suppressor gene. One straightforward hypothesis is that the tumor spectrum is modulated by the rate of the loss of the wildtype allele in specific tissues. Conditional somatic mutation of a tumor suppressor gene is a powerful way to address this hypothesis, because it enables to artificially increase this rate in a tissue-specific manner. Such mutation could be obtained early in Schwann cell development by exploiting the specificity of the $P O$ promoter that controlled the Cre-mediated recombination of the floxed $N f 2$ gene. P0Cre; $N f 2^{\mathrm{KO} 3 / \text { flox } 2}$ mice indeed developed schwannomas in which the floxed allele was recombined, thereby demonstrating that Nf2 inactivation is the rate-limiting step in murine Schwann cell tumorigenesis. This conclusion is reinforced by the observation of schwannomas in P0Cre; Nf2 flox $2 /$ flox 2 mice. Such mice have two functional Nf2 genes at the germ-line level but are prone to mutate both alleles in Cre-expressing tissues. P0Cre ${ }^{\mathrm{C}}$; $f 2^{\text {flox2/flox2 }}$ mice showed the highest incidence of benign and malignant schwannomas (35\%), all with biallelic Cre-mediated deletion of the floxed exon 2. The first histological lesion associated with murine Schwann cell tumorigenesis is probably represented by Schwann cell hyperplasia. It was found from an early age on (17-days-old), at very high frequencies in POCre; $N f 2^{\text {flox } 2 / \text { flox } 2}$ and POCre; $N f 2^{\mathrm{KO} 3 / \text { flox2 }}$ mice, but not in $N f 2^{\mathrm{KO} 3 /+}, N f 2^{\Delta 2 /+}$, or P0Cre; $N f 2^{\text {flox } 2 /+}$ mice. Taken together these observations indicate that Schwann cell hyperplasia is an early manifestation of the biallelic Nf2 inactivation. In contrast, Schwann cell tumors appeared late in life, the frequency was at most one tumor per mouse and not all mice of one line developed such tumors. These results strongly suggest that Schwann cell hyperplasia does not progress rapidly to tumors. Therefore, whereas biallelic inactivation of $N f 2$ is essential for initiation of Schwann cell tumor development, it is not sufficient and additional genetic or epigenetic events are required. Vestibular schwannomas, the hallmark tumors of human NF2, have not been found in the conditional Nf2 knockout mice. The VIIIth cranial nerve of man and mice are different, because human vestibular bipolar ganglion cells are devoid of myelin sheaths, whereas in adult vertebrates (including mouse and rat) the same cells are myelinated (Sterkers et al. 1987). Whether this difference is relevant for the discrepancy in tumorigenesis of theVIIIth cranial nerve of both species remains to be elucidated.

Wild-type promyelinating Schwann cells exit the cell cycle once they have established a one-to-one relationship with the axons and then myelination begins (Zorick and Lemke 1996). As shown by ultrastructural analysis of Schwann cells of the sciatic nerve of $\mathrm{P} 0 \mathrm{Cr} e^{\mathrm{A}}$; $N f 2^{\text {flox } 2 / \text { flox } 2}$ mice, these cells can myelinate but their interaction with the axon is profoundly altered. Presently, it is not known whether this anomaly is due to a deficiency in the cellular crosstalk, which is normally triggered by the association of the Schwann cell with the axolemma (Jessen and Mirsky 1994), or to abnormal adhesive and/or motile properties of the mutant Schwann cells (Gutmann et al. 1999). Both hypotheses are supported by the role of schwannomin in membrane dynamics (Gonzalez-Agosti et al. 1996) and cell adhesion (Gutmann et al. 1999).

Our results indicate that the Nf2 protein is involved in migration, growth, and/or differentiation of cells derived from the neural crest, because the majority of the P0Cre conditional Nf2 knockout mice develop various signs of neurocristopathy, a concept introduced by Bolande (1974). Already at E9.5 we observed Cre recombination 
activity marked by reporter lacZ expression mostly in the area of the neural crest migration. Consequently, all descendants of these P0-expressing neural crest cells in the conditional $N f 2$ knockout mice carried and transmitted the inherited exon 2-deleted $N f 2$ allele(s) even when the $P O$ promoter was subsequently silenced. Examples of such descendants in the adult peripheral nerve are myelinated $\left(\mathrm{PO}^{+}, \mathrm{Krox}-20^{+}\right)$and non-myelinated $\left(\mathrm{PO}^{-}\right.$, Krox$20^{-}$) Schwann cells that both showed Cre-mediated recombination. Therefore, hyperplasia not only of Schwann cells, but also of other neural crest-derived cells, such as odontoblasts, osteoblasts and renal tubular cells plus the cranio-facial abnormalities are probably the result of the biallelic $N f 2$ mutation in a common neural crest precursor. The frequently observed osseous metaplasia in various tissues (including brain) of the P0Cre conditional Nf2 knockout mice is likely the result of $N f 2$ gene inactivation in neural crest-derived cells. These observations suggest that in NF2 patients the frequently seen non-tumoral intracranial calcifications, subcapsular lens opacities, and cataracts (Mayfrank et al. 1990) may also be regarded as manifestations of neurocristopathy. Recently, it has been shown that the murine corneal endothelium (of neural crest origin like the corneal stroma and anterior iris) is required to prevent attachment of the lens and iris to the corneal stroma (Reneker et al. 2000). Therefore, persistent connection between lens and cornea (or iris) as seen in the $\mathrm{POCre} ; \mathrm{Nf}^{\text {flox } 2 / \text { flox } 2}$ mice has probably resulted from loss of $N f 2$ function.

Previously, we have reported on transgenic mice expressing a $\Delta$ exon2-3 mutant schwannomin under the control of the same PO promoter (Giovannini et al. 1999). The conditional homozygous Nf2 knockout mice and Nf2 mutant transgenic mice show a similar Schwann cell phenotype, as both develop Schwann cell tumors and hyperplasia at a comparable frequency. Notwithstanding, the conditional knockout model mimics more closely the human situation by mutation of both endogenous $N f 2$ alleles, whereas in the transgenic model the $\Delta$ exon2-3 mutant protein exerts the dominant oncogenic effect in cells with two functional endogenous alleles. The Schwann cell phenotype is not seen in $\mathrm{POCre} ; \mathrm{Nf}^{\mathrm{flox} 2 /+}$ mice, indicating that the endogenous expression level of one mutant allele is insufficient to reveal its dominant effect.

We have not seen other signs of neurocristopathy in the transgenic mice overexpressing the $\Delta$ exon2-3 mutant protein. This may be explained by the low level of transgene expression in neural crest cells during embryonic development, in contrast to the readily detectable Cre expression in adult peripheral nerve: At E12.5 no Cre expression in neural crest cells could be detected by immunostaining despite the evidence of Cre-mediated recombination. It is also possible that the interacting target protein for the $\Delta$ exon2-3 mutant protein was not expressed in the neural crest cells other than Schwann cell precursor cells.

The present mouse model recapitulates several features observed in NF2 patients, specifically Schwann cell hyperplasia, Schwann cell tumors, cataracts, and cerebral calcifications. All these manifestations have been exclusively observed in mice that were prone to inactivate both alleles of the $N f 2$ gene in Schwann cells and in a small subset of neural crest cells. Importantly, meningioma, a frequent manifestation of the human NF2 disease was not observed in these mice suggesting that meningioma progenitor cells are not permissive to the $P O$ promoter. The use of different promoters to direct Cre expression to meningioma precursor cells could be exploited to validate this hypothesis. The present model, which develops schwannoma by a mechanism that is functionally similar to that observed in human patients, provides a powerful approach to investigate the tumor suppressive function of the $N f 2$ gene and a new tool to explore novel therapeutic interventions prior to trials in humans.

\section{Materials and methods}

Generation of $\mathrm{Nf2} 2^{\mathrm{KO} / /+}, \mathrm{Nf} 2^{\Delta 2 /+}$, and $\mathrm{Nf} 2^{\text {flox2/+ }}$ ES cells

A 17.0-kb Nf2 genomic clone encompassing exons 2 to 4 was isolated from a mouse 129/Ola genomic library. For construction of the different Nf2 targeting vectors, a 12.4-kb NotI-KpnI fragment was used.

To generate the $\mathrm{Nf2} 2^{\mathrm{KO} /+}$ ES cells, the $12.4-\mathrm{kb}$ fragment was subcloned in a modified pBR322 vector containing a NaeI-KpnI polylinker from pBluescript KS II (Stratagene). A 5.0-kb fragment containing an IRESLacZ/PGKHyg cassette was inserted into the BstBI site of exon 3 (codon 87). The ApaI-KpnI Nf2KO3 targeting fragment was electroporated into ES cells of the E14 subclone IB10 (Robanus-Maandag et al. 1998) and hygromycin B-resistant cells were selected as described (te Riele et al. 1992). For Southern blot analysis of the ES cell clones, the 3' external probe A (0.5-kb KpnI-XhoI fragment) was used. Two selected clones were verified for the correct karyotype.

To generate the $N f 2^{\Delta 2 /+}$ ES cells, a 2.9-kb BamHI fragment containing a floxed PGKHprt mini-gene was inserted into the BamHI site $0.4 \mathrm{~kb}$ downstream of exon 2 (in an orientation opposite to the Nf2 gene). A third loxP site and an extra PstI site were introduced into the EcoRI site 1.3-kb upstream of exon 2. The NotI-KpnI Nf2lox2 targeting fragment was electroporated into ES cells of the hypoxanthine/guanine phosphoribosyltransferase (Hprt)-deficient, 129/Ola-derived, HM-1 cell line, and HAT-resistant cells were selected for 7 days as described (te Riele et al. 1992). By Southern blot analysis of ES cell clones, using probe A and XbaI-SacI-digested DNA, we identified 76 homologous recombinants out of $192 \mathrm{HAT}^{\mathrm{R}}$ clones. In four independent clones, the presence of the loxP site upstream of exon 2 was confirmed by Southern blot analysis using PstI digestion and probe B (a 221-bp PCR fragment, 120 bp 3' of the ApaI site). In the second step, plasmid pIC-Cre (Gu et al. 1993) was transfected into two genetically modified ES cell clones to transiently express Cre recombinase. For electroporation of $2 \mu \mathrm{g}$ of supercoiled plasmid DNA into an equivalent of $20 \mathrm{~cm}^{2} \mathrm{Nf} 2^{10 \times 2 /+}$ ES cells, a Bio-Rad Gene Pulser was used $(0.8 \mathrm{kV}, 1 \mu \mathrm{F}$, discharge $0.1 \mathrm{msec}, 0.4 \mathrm{~cm}$ electrode distance, cells in $200 \mu \mathrm{l}$ medium). Electroporated cells were plated on $2 \times 60 \mathrm{~cm}^{2}$ mouse embryonic fibroblasts (MEFs), medium was refreshed $24 \mathrm{hr}$ after electroporation, cells were trypsinized $48 \mathrm{hr}$ after electroporation, counted, and replated at a density of $4 \times 10^{5}$ cells per $60 \mathrm{~cm}^{2}$ in medium. After either $72 \mathrm{hr}$ or $96 \mathrm{hr}$, selection with 6-thioguanine (6-TG; $10 \mu \mathrm{g} / \mathrm{ml}$ ) was started and continued for 4 days or 3 
days, respectively. Selected colonies were picked and multiplex PCR analysis with a combination of three primers (P4: 5'CTTCCCAGACAAGCAGGGTTC-3'; P5: 5'-GAAGGCAGCTTCCTTAAGTC-3'; P6: 5'-CTCTATTTGAGTGCCTGCCATG-3') was used to identify both Cre-mediated deletions lacking the PGKHprt gene.

Generation and genotyping of Nf2 mutant and P0Cre transgenic mice

Germ-line chimeras were generated by injection of 12-15 Nf2 mutant ES cells into C57Bl/6 blastocysts and crossed with $\mathrm{FVB} / \mathrm{N}$ mice to produce outbred heterozygous offspring.

To generate P0Cre transgenic mice, a 1.4-kb EcoRI-MluI fragment derived from pOG231 (O'Gorman et al. 1997) was bluntend ligated into the EcoRV site of a cassette between the 1.1-kb rat $P O$ promoter and $1 \mathrm{~kb}$ of the rabbit $\beta$-globin intron and polyadenylation signal. The purified NotI-SalI 3.4-kb P0Cre transgene fragment was injected into $\mathrm{FVB} / \mathrm{N}$ zygotes as described (Akagi et al. 1997).

The genotypes of all offspring were analyzed by PCR or Southern blot analysis on tail-tip DNA. Using multiplex PCR analysis with a combination of primers P1 (5'-GCCTGCTCTTTACTGAAGGCTC-3'), P2 (5'-CAGTGTGGAAGTGTTTGTGGTC$\left.3^{\prime}\right)$, and P3 (5'-GTGTTGGATCATGATGTTTCG-3' $\left.{ }^{\prime}\right)$ the $\mathrm{Nf2} 2^{\mathrm{KO} 3}$ and $\mathrm{Nf2}^{+}$allele were detected yielding a 440-bp and 250bp product, respectively. The $N f 2^{\text {flox } 2}$ allele was detected with primers P4 (5'-CTTCCCAGACAAGCAGGGTTC-3') and P5 (5'-GAAGGCAGCTTCCTTAAGTC-3') yielding a 442-bp $\left(N f 2^{\text {flox2 }}\right.$ allele) and a 305 -bp $\left(N f 2^{+}\right.$allele) product. The $N f 2^{\Delta 2}$ allele was detected with primers $\mathrm{P} 5$ and $\mathrm{P} 6\left(5^{\prime}\right.$-CTCTATTTGAGTGCGTGCCATG-3') yielding a 338-bp ( $N f 2^{\Delta 2}$ allele) and a $2.1-\mathrm{kb}\left(\mathrm{Nf2}^{+}\right.$allele) product. P0Cre transgenes were determined with the primers Cre3 (5' -TCCAATTTACTGACCGTACACC-3') and Cre4 (5'-CGTTTTCTTTTCGGATCC-3') yielding a 372-bp product. In the case of Southern blot analysis, the $\mathrm{Nf} 2^{\mathrm{KO} 3}$ and $\mathrm{Nf} 2^{\text {flox2 }}$ alleles were detected using restriction enzymes and probes as described for the identification of homologous recombinant ES cell clones. To detect P0Cre transgenes, the PCR product generated with primers Cre3 and Cre4 and labeled by random priming served as probe on EcoRV-digested DNA.

\section{$R T-P C R$}

Total RNA was extracted from brain and sciatic nerves of mice using Trizol LS Reagent (GIBCO BRL). The reverse transcription reaction was carried out using a RNA-PCR core kit (Perkin Elmer Cetus). PCR was performed on the resulting cDNA using the primers Nf2-S1 (5'-CATGAGCTTCAGCTCACTCAAGAGGAAG-3') and Nf2-AS5 (5'-ATCCCCGCTTGTGCACAGAGG-GGTCATAG-3'). After agarose gel electrophoresis, RTPCR products were purified following the manufacturer's protocol (Qiagen) and directly sequenced using a dye terminator sequencing kit (Applied Biosystems).

Western blot analysis, immunoprecipitation, and immunoblotting

Protein analysis of mouse tissues by Western blotting has been described (Giovannini et al. 1999). To detect Cre, affinity-purified polyclonal rabbit anti-Cre antibody (Novagen) was used. For immunoprecipitation, rabbit polyclonal antibody anti-NF2Nter A-19 (sc-331, Santa Cruz Biotechnology) was used, directed against exon 1-encoding amino acids 2-21 of human schwannomin that are conserved in the mouse. For immunob- lotting, affinity-purified rabbit polyclonal anti-NF2-Cter C-18 (sc-332, Santa Cruz Biotechnology) was used, directed against the carboxyl terminus (amino acids 570-587) of human schwannomin.

Horseradish peroxidase-conjugated donkey anti-rabbit Ig antibody (Amersham) was coupled to the primary antibodies and immunocomplexes were detected as described (Giovannini et al. 1999).

\section{Histological and electron microscopical analysis,} immunohistochemistry

Mice were sacrificed when moribund or held until 24 months of age. Histological analysis was performed as described (Giovannini et al. 1999).

For electron microscopical analysis, tissues were left overnight in Karnovsky's fixative, rinsed in s-collidine buffer, and postfixed for $1 \mathrm{hr}$ in $1 \%$ osmium tetroxide as described (Erlandson and Woodruff 1982). Specimens then were embedded in epoxy resin and examined with a transmission electron microscope.

For indirect immunoperoxidase assay with $\mathrm{DAB}$ substrate, the rabbit polyclonal antisera anti-mouse p75 LNGFR (Chemicon International), anti-bovine S-100 protein (DAKO), anti-cow glial fibrillary acidic protein (GFAP; DAKO), anti-Cre (Novagen), and anti-krox-20 (BABCO) were used and detected with subsequently horse radish peroxidase-conjugated goat anti-rabbit Ig antibody (Amersham) as described (Giovannini et al. 1999). For detection of $\beta$-galactosidase activity tissues were fixed and stained with X-gal as described (Akagi et al. 1997).

\section{Acknowledgments}

We thank A. Begue for the mouse 129/Ola genomic library; G. Lemke, S. O'Gorman, and C. Tölg for plasmids; K. van VeenBuurman and R. Bobeldijk for zygote and blastocyst injections; F. van der Ahé, K. Ankama, L. Aussepé, N. Bosnie, T. Maidment, H. Raasø, L. Rijswijk, and A. Zwerver for animal care; R. Regnerus for genotyping of the mice; J. Bulthuis, K. de Goeij, D. Hoogervorst, L. Kuijper-Pietersma, and E. van Muylwijk for histotechnical assistance; R. Erlandson for electron microscopy; A. Gabreëls-Festen and P. Topilko for discussion on the Schwann cell phenotypes; H. te Riele for critically reading the manuscript. We are grateful to the Institut Curie for housing part of the transgenic mouse colony during the course of the study. This work was supported by grants from the Commission of the European Communities (BMH-CT96-1518; E.R.-M.), Ligue Nationale Française contre le Cancer, Association pour la Recherche sur le Cancer, and by postdoctoral fellowships from ECC (ERB4001GT941265; M.G.), European Molecular Biology Organization (EMBO) (M.G.), Human Frontier Science Program (M.G.), Societé de Secours des Amis des Sciences (M.G.), and INSERM (M.N.-K.).

The publication costs of this article were defrayed in part by payment of page charges. This article must therefore be hereby marked "advertisement" in accordance with 18 USC section 1734 solely to indicate this fact.

\section{References}

Akagi, K., Sandig, V., Vooijs, M., Van der Valk, M., Giovannini, M., Strauss, M., and Berns, A. 1997. Cre-mediated somatic site-specific recombination in mice. Nucleic Acids Res. 25: 1766-1773. 
Bianchi, A.B., Mitsunaga, S.-I., Cheng, J.Q., Klein, W.M., Jhanwar, S.C., Seizinger, B., Kley, N., Klein-Szanto, A.J.P., and Testa, J.R. 1995. High frequency of inactivating mutations in the neurofibromatosis type 2 gene (NF2) in primary malignant mesotheliomas. Proc. Natl. Acad. Sci. 92: 1085410858.

Bolande, R. 1974. The neurochristopathies. A unifying concept of disease arising in neural crest maldevelopment. Hum. Pathol. 5: 409-420.

Couly, G.F., Coltey, P.M., and Le Douarin, N.M. 1993. The triple origin of skull in higher vertebrates: A study in quailchick chimeras. Development 117: 409-429.

Deguen, B., Merel, P., Goutebroze, L., Giovannini, M., Reggio, H., Arpin, M., and Thomas, G. 1998. Impaired interaction of naturally occurring mutant NF2 protein with actin-based cytoskeleton and membrane. Hum. Mol. Genet. 7: 217-226.

Eldridge, R. 1981. Central neurofibromatosis with bilateral acoustic neuroma. Adv. Neurol. 29: 57-65.

Erlandson, R.A. and Woodruff, J.M. 1982. Peripheral nerve sheath tumors: An electron microscopic study of 43 cases. Cancer 49: 273-287.

Giovannini, M., Robanus-Maandag, E., Niwa-Kawakita, M., van der Valk, M., Woodruff, J.M., Goutebroze, L., Merel, P., Berns, A., and Thomas, G. 1999. Schwann cell hyperplasia and tumors in transgenic mice expressing a naturally occurring mutant NF2 protein. Genes \& Dev. 13: 978-986.

Gonzalez-Agosti, C., Xu, L., Pinney, D., Beauchamp, R., Hobbs, W., Gusella, J., and Ramesh, V. 1996. The merlin tumor suppressor localizes preferentially in membrane ruffles. Oncogene 13: 1239-1247.

Gu, H., Zou, Y.R., and Rajewsky, K. 1993. Independent control of immunoglobulin switch recombination at individual switch regions evidenced through Cre-loxP-mediated gene targeting. Cell 73: 1155-1164.

Gu, H., Marth, J.D., Orban, P.C., Mossmann, H., and Rajewsky, K. 1994. Deletion of a DNA polymerase beta gene segment in $\mathrm{T}$ cells using cell type-specific gene targeting. Science 265: 103-106.

Gutmann, D.H., Sherman, L., Seftor, L., Haipek, C., Hoang Lu, K., and Hendrix, M. 1999. Increased expression of the NF2 tumor suppressor gene product, merlin, impairs cell motility, adhesion and spreading. Hum. Mol. Genet. 8: 267-275.

Jacks, T. 1996. Tumor suppressor gene mutations in mice. Annu. Rev. Genet. 30: 603-636.

Jessen, K.R. and Mirsky, R. 1994. Schwann cell biology. In The neurofibromatoses. A clinical and pathogenetic overview (ed. S.M. Huson and R.A.C. Hughes), pp. 95-134. Chapman \& Hall, London, UK.

Kaiser-Kupfer, M.I., Freidlin, V., Datiles, M.B., Edwards, P.A., Sherman, J.L., Parry, D., McCain, L.M., and Eldridge, R. 1989. The association of posterior capsular lens opacities with bilateral acoustic neuromas in patients with neurofibromatosis type 2. Arch. Ophthalmol. 107: 541-544.

Koga, H., Araki, N., Takeshima, H., Nishi, T., Hirota, T., Kimura, Y., Nakao, M., and Saya, H. 1998. Impairment of cell adhesion by expression of the mutant neurofibromatosis type 2 (NF2) genes which lack exons in the ERM-homology domain. Oncogene 17: 801-810.

Lee, M., Brennan, A., Blanchard, A., Zoidl, G., Dong, Z., Tabernero, A., Zoidl, C., Dent, M.A., Jessen, K.R., and Mirsky, R. 1997. P0 is constitutively expressed in the rat neural crest and embryonic nerves and is negatively and positively regulated by axons to generate non-myelin-forming and myelinforming Schwann cells, respectively. Mol. Cell. Neurosci. 8: $336-350$

Lumsden, A.G. 1988. Spatial organization of the epithelium and the role of neural crest cells in the initiation of the mammalian tooth germ. Development 103: 155-169.

MacCollin, M. and Gusella, J. 1998. Neurofibromatosis type 2. In The genetic basis of human cancer (ed. B. Vogelstein and K.W. Kinzler), pp. 443-453. McGraw-Hill, USA.

Mayfrank, L., Mohadjer, M., and Wullich, B. 1990. Intracranial calcified deposits in neurofibromatosis type 2. A CT study of 11 cases. Neuroradiology 32: 33-37.

McClatchey, A.I., Saotome, I., Ramesh, V., Gusella, J.F., and Jacks, T. 1997. The NF2 tumor suppressor gene product is essential for extraembryonic development immediately prior to gastrulation. Genes \& Dev. 11: 1253-1265.

McClatchey, A.I., Saotome, I., Mercer, K., Crowley, D., Gusella, J.F., Bronson, R.T., and Jacks, T. 1998. Mice heterozygous for a mutation at the NF2 tumor suppressor locus develop a range of highly metastatic tumors. Genes \& Dev. 12: 11211133.

Messing, A., Behringer, R.R., Hammang, J.P., Palmiter, R.D., Brinster, R.L., and Lemke, G. 1992. P0 promoter directs expression of reporter and toxin genes to Schwann cells of transgenic mice. Neuron 8: 507-520.

Messing, A., Behringer, R.R., Wrabetz, L., Hammang, J.P., Lemke, G., Palmiter, R.D., and Brinster, R.L. 1994. Hypomyelinating peripheral neuropathies and schwannomas in transgenic mice expressing SV40 T-antigen. I. Neurosci. 14: 3533-3539.

Nishi, T., Takeshima, H., Hamada, K., Yoshizato, K., Koga, H., Sato, K., Yamamoto, K., Kitamura, I., Kochi, M., Kuratsu, J.-I., Saya, H., and Ushio, Y. 1997. Neurofibromatosis 2 gene has novel alternative splicings which controls intracellular protein binding. Int. J. Oncology 10: 1025-1029.

O'Gorman, S., Dagenais, N.A., Qian, M., and Marchuk, Y. 1997. Protamine-Cre recombinase transgenes efficiently recombine target sequences in the male germ line of mice, but not in embryonic stem cells. Proc. Natl. Acad. Sci. 94: 1460214607.

Reneker, L.W., Silversides, D.W., Xu, L., and Overbeek, P.A. 2000. Formation of corneal endothelium is essential for anterior segment development: A transgenic mouse model of anterior segment dysgenesis. Development 127: 533-542.

Robanus-Maandag, E., Dekker, M., van der Valk, M., Carrozza, M.L., Jeanny, J.C., Dannenberg, J.H., Berns, A., and te Riele, H. 1998. p107 is a suppressor of retinoblastoma development in pRb-deficient mice. Genes \& Dev. 12: 1599-1609.

Rouleau, G.A., Mérel, P., Lutchman, M., Sanson, M., Zucman, J., Marineau, C., Hoang-Xuan, K., Demczuk, S., Desmaze, C., Plougastel, B. et al. 1993. Alteration in a new gene encoding a putative membrane-organizing protein causes neurofibromatosis type 2. Nature 363: 515-521.

Sato, N., Funayama, N., Nagafuchi, A., Yonemura, S., Tsukita, S., and Tsukita, S. 1992. A gene family consisting of ezrin, radixin and moesin. Its specific localization at actin filament/plasma membrane association sites. J. Cell Sci. 103: $131-143$.

Sekido, Y., Pass, H.I., Bader, S., Mew, D.J.Y., Christman, M.F., Gazdar, A.F., and Minna, J.D. 1995. Neurofibromatosis type 2 (NF2) gene is somatically mutated in mesothelioma but not in lung cancer. Cancer Res. 55: 1227-1231.

Sterkers, J.M., Perre, J., Viala, P., and Foncin, J.F. 1987. The origin of acoustic neuromas. Acta Otolaryngol. 103: 427431.

Sternberg, N. and Hamilton, D. 1981. Bacteriophage P1 sitespecific recombination. I. Recombination between loxP sites. J. Mol. Biol. 150: 467-486.

Takeshima, H., Izawa, I., Lee, P.S.Y., Safdar, N., Levin, V.A., and Saya, H. 1994. Detection of cellular proteins that interact 
Giovannini et al.

with the NF2 tumor suppressor gene product. Oncogene 9: 2135-2144.

te Riele, H., Maandag, E.R., and Berns, A. 1992. Highly efficient gene targeting in embryonic stem cells through homologous recombination with isogenic DNA constructs. Proc. Nat1. Acad. Sci. 89: 5128-5132.

Topilko, P., Schneider-Maunoury, S., Levi, G., Baron-Van Evercooren, A., Chennoufi, A.B., Seitanidou, T., Babinet, C., and Charnay, P. 1994. Krox-20 controls myelination in the peripheral nervous system. Nature 371: 796-799.

Trofatter, J.A., MacCollin, M.M., Rutter, J.L., Murrell, J.R., Duyao, M.P., Parry, D.M., Eldridge, R., Kley, N., Menon, A.G., Pulaski, K. et al. 1993. A novel moesin-, ezrin-, radixinlike gene is a candidate for the neurofibromatosis 2 tumor suppressor. Cell 72: 791-800.

Wiestler, O.D. and Radner, H. 1994. Pathology of neurofibromatosis 1 and 2. In The neurofibromatoses. A clinical and pathogenetic overview (ed. S.M. Huson and R.A.C. Hughes), pp. 135-159. Chapman \& Hall, London, UK.

Willis, R.A. 1958. The embryonic tumours and teratomas. In The borderland of embryology and pathology, pp. 410-454. Butterworth and Co., London, UK.

Yamauchi, Y., Abe, K., Mantani, A., Hitoshi, Y., Suzuki, M., Osuzu, F., Kuratani, S., and Yamamura, K. 1999. A novel transgenic technique that allows specific marking of the neural crest cell lineage in mice. Dev. Biol. 212: 191-203.

Zorick, T.S. and Lemke, G. 1996. Schwann cell differentiation. Curr. Opin. Cell Biol. 8: 870-876. 


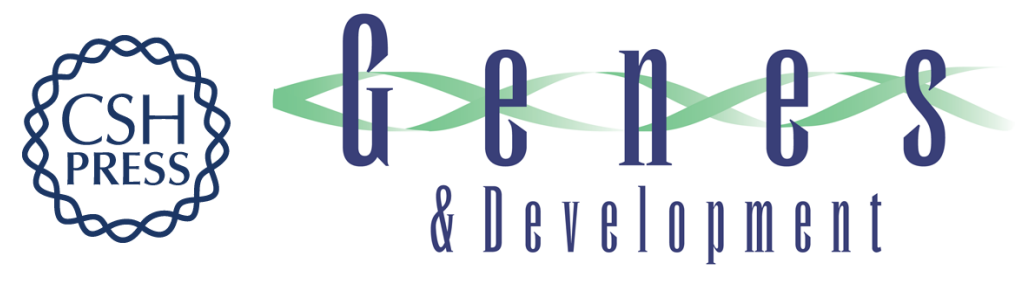

\section{Conditional biallelic Nf2 mutation in the mouse promotes manifestations of human neurofibromatosis type 2}

Marco Giovannini, Els Robanus-Maandag, Martin van der Valk, et al.

Genes Dev. 2000, 14:

Access the most recent version at doi:10.1101/gad.14.13.1617

References This article cites 36 articles, 13 of which can be accessed free at: http://genesdev.cshlp.org/content/14/13/1617.full.html\#ref-list-1

License

Email Alerting

Receive free email alerts when new articles cite this article - sign up in the box at the top Service right corner of the article or click here.

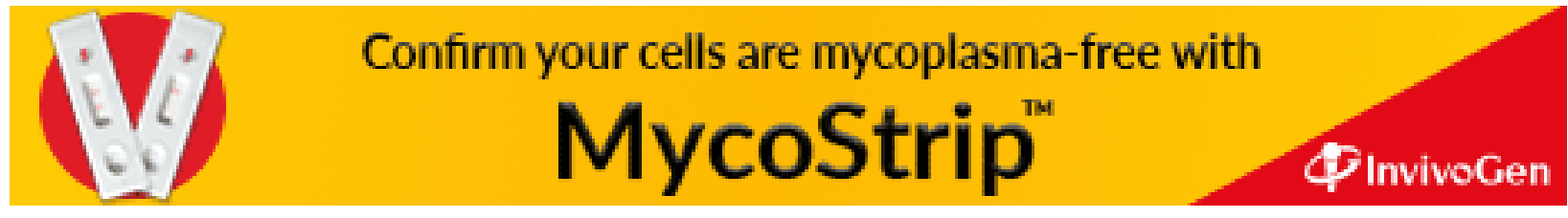

